Revista Cógnito v.2:2 (2020) 280 - 318

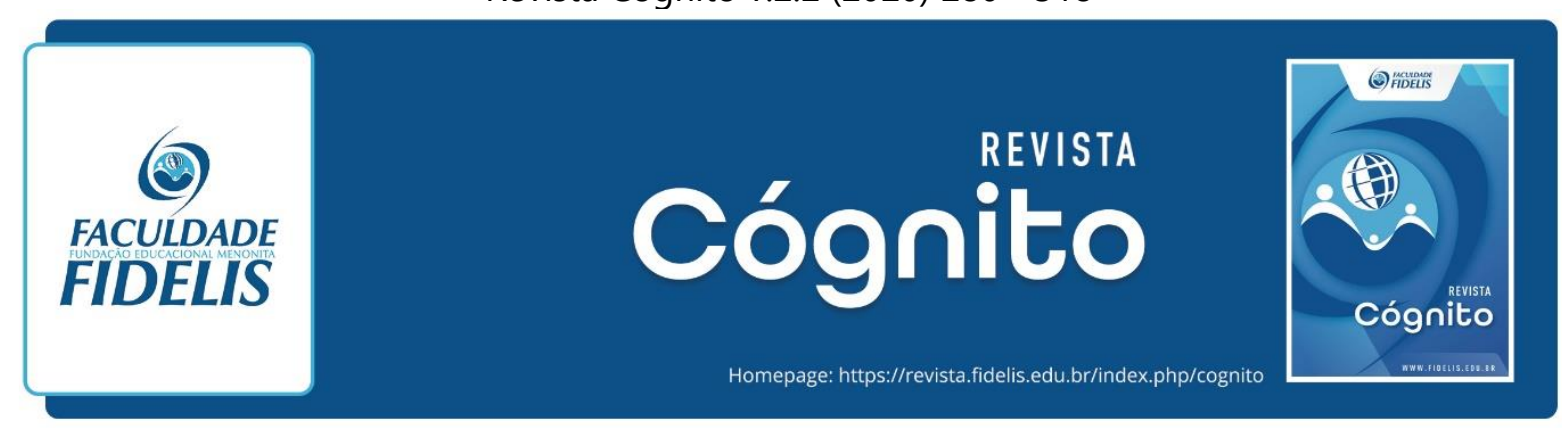

\title{
PASTORES TAMBÉM SÃO OVELHAS - IMPORTANDO-SE PARA CUIDAR DAQUELES QUE CUIDAM
}

\section{PASTORS ARE ALSO SHEEP: OFFERING PASTORAL CARE TO THOSE WHO TEND THE SHEEP}

\author{
Siegfrid Wedel ${ }^{1}$ \\ Arthur Wesley Dück²
}

\section{RESUMO}

Este artigo ocupa-se com a pessoa do pastor da igreja como ser humano, tendo em vista suas crises ministeriais e pessoais. O pastor como cuidador de pessoas é abordado na perspectiva de que o mesmo é, também, uma ovelha entre ovelhas. A dimensão de cuidar e de ser cuidado é amplamente discutida e avaliada. Destaca-se a importância do cuidado pessoal e pastoral que deve ser proporcionado ao pastor como pessoa. No primeiro capítulo são esboçadas algumas crises e armadilhas que justificam esta necessidade urgente dos agentes pastorais. No segundo são apresentados os desafios que este cuidado envolve tanto para a igreja quanto para o próprio pastor. Uma pesquisa de campo com 81 pastores confirma e atesta a necessidade e a importância de um pastoreio e mentoreamento de pastores. No terceiro capítulo são apresentadas várias iniciativas de cuidados voltados intencionalmente para a pessoa do pastor. O pastor pode e deve ser cuidado. Há um clamor por "pastor de pastores".

PALAVRAS-CHAVES: Cuidador de pessoas. Crises. Necessidades. Cuidado pessoal. Pastor de pastores.

\begin{abstract}
This study is concerned with the pastor as a human being. It looks at him/her in his/her personal and ministerial crises. The pastor as a shepherd of people is approached from the perspective that he is also a sheep among other sheep. The issue of caring for others and being cared for is richly discussed and evaluated. Emphasis is placed on the need for personal and pastoral care that should be offered to the pastor as a person. In the first chapter some crises and pitfalls are outlined that justify the urgent need for pastoral care for those in ministry. In

\footnotetext{
${ }^{1}$ Especialista em Ministério Pastoral pela Faculdade Fidelis

${ }^{2}$ Doutor em Teologia pela Escola Superior de Teologia - EST. Docente do curso de Bacharelado em Teologia da Faculdade Fidelis. arthur.duck@fidelis.edu.br
} 
the second, the challenges that this pastoral care generates for the church and for the pastor are presented. A research with 81 pastors shows and confirms the need and significance of shepherding and mentoring pastors. Finaly several attempts at pastoral care for pastors are presented. Pastors can and should be cared for. There is a call for pastors who will shepherd other pastors.

KEYWORDS: Pastor. Crises. Needs. Pastoral care. Shepherding pastors.

\section{INTRODUÇÃO}

Recentemente o cuidado aos cuidadores de pessoas tem sido objeto de estudo na psicologia, na medicina, na teologia e tantos outros campos, onde profissionais e voluntários atuam na área de ajuda a outras pessoas. Será que o pastor, nesta consideração, também necessita ser pastoreado?

No mundo evangélico tem crescido a preocupação sobre o cuidado dado às lideranças pastorais: Será que o pastor, como cuidador de outros, está sendo devidamente cuidado? O pastor como pessoa, como "ovelha", não necessita também de um pastor ou de um mentor em sua própria vida? De que maneira pastores poderiam ser cuidados e pastoreados de forma mais eficiente e preventiva?

Escândalos de repercussão nacional, envolvendo lideranças pastorais, justificam estas preocupações. Como ajudar os pastores para que terminem bem seu ministério?

A primeira parte desta monografia destaca o chamado do pastor na dimensão do cuidado de pessoas e o fato de que ele mesmo, na condição de ser humano, está sujeito a crises e conflitos, como outro membro da comunidade. Nesta perspectiva, pastor também é "ovelha" e, como tal, precisa ser apascentado. Necessita de um pastoreio adequado e específico. Fica evidente que o pastor também precisa de pastor, assim como um conselheiro precisa de conselheiro e um médico precisa de outro médico. Constata-se que os pastores, na sua grande maioria, são pessoas solitárias e prestam contas eclesiásticas e administrativas, mas poucas vezes, tem alguém com quem possam abrir-se a respeito das suas lutas e dilemas pessoais. Observações e pesquisas apontam para o fato de que muitos pastores estão sendo negligenciados quanto ao cuidado de suas vidas como pessoas.

Nesta monografia pretende-se abordar a importância do cuidado pessoal e pastoral que deve ser proporcionado ao pastor como pessoa. A reflexão psico-social e teológica sobre a dimensão de cuidar e de ser cuidado tem o propósito de contribuir para uma conscientização 
maior dos pastores e das lideranças eclesiais sobre sua necessidade, bem como seu valor e benefício para as respectivas igrejas.

Como referência principal para o embasamento teórico foi utilizado o livro Cuidando de quem cuida - um olhar de cuidados aos que ministram a Palavra de Deus, da autoria de Roseli M. Kühnrich de Oliveira, fruto da sua dissertação de mestrado.

Foi realizado uma pesquisa de campo referente ao pastoreio de pastores em três denominações evangélicas menonitas no Brasil, a saber: AEM (Aliança Evangélica Menonita), AIMB (Associação das Igrejas Menonitas do Brasil) e COBIM (Convenção Brasileira das Igrejas Irmãos Menonitas). Resultados e implicações serão comentados e analisados na sequência.

O objetivo da última parte é referenciar algumas iniciativas para o desenvolvimento de um ministério voltado para o cuidado e acompanhamento específico de pastores. Aquele que pastoreia também precisa ser pastoreado.

O presente estudo pretende auxiliar a igreja e a comunidade a perceber o pastor como pessoa, alguém igual entre iguais, e em sua humanidade, com necessidades e lutas comuns, e não como um destacado e idealizado "profissional da Palavra de Deus" ou como sendo aquele "líder espiritual sempre-forte" da igreja.

\section{CRISES E ARMADILHAS NO MINISTÉRIO PASTORAL}

O pastor é a última pessoa de quem se espera ouvir falar de crise pessoal. Durante muitos anos foi cunhada uma imagem, um tanto mítica, do cuidador pastoral como sendo alguém acima da média humana, imune aos reveses comuns aos simples mortais. Muitos ignoram, por ingenuidade ou por conveniência, que o agente do pastoreio também está sujeito às fragilidades, limitações e falhas, como os próprios pastoreados.

Primeiramente, é necessário conceituar a atuação pastoral para, então, abordar dificuldades e aspectos que ameaçam seu desempenho.

\subsection{COMPREENSÃO DO CHAMADO PARA APASCENTAR E CUIDAR}

A palavra pastor remete para a atividade pastoril do passado, tomando sua designação emprestada da figura do pastor de ovelhas. Seu trabalho consistia em apascentar e cuidar do rebanho: ele guiava as ovelhas, andando na sua frente, providenciava pastagens e água, e também defendia e guardava todo o rebanho de qualquer ataque ou ameaças. 
Desta figura é extraído o conceito de pastoreio de pessoas, ou seja, a ação de cuidar de outras pessoas. Assim considerado, a atuação pastoral encerra, principalmente, a categoria do cuidado. Na atribuição eclesial, no entanto, nem sempre este aspecto recebe a devida atenção.

Do cuidado exemplar de Deus pelo seu povo, e igualmente de Jesus Cristo, revelado como sendo o Bom Pastor ${ }^{3}$, é possível definir alguns contornos do ministério do pastor na atualidade. Autores, como Roseli Kühnrich de Oliveira, referem-se, então, à poimênica para descreverem a ação do cuidado pastoral. A palavra poimênica não é dicionarizada na língua portuguesa, mas amplamente utilizada no meio acadêmico e teológico e, muitas vezes, em conexão com o aconselhamento pastoral. O termo é derivado da palavra grega poimen ${ }^{4}$, que simplesmente significa pastor (de ovelhas) (Oliveira, 2005, p.33).

Nesta perspectiva, o ministério pastoral deve ser compreendido essencialmente como dimensão de ajuda e cuidado proporcionado às pessoas no contexto da igreja cristã. Isto legitimiza categorizar pastores como sendo aqueles que cuidam de outras pessoas. Sua tarefa e trabalho consistem principalmente em apascentar e pastorear vidas humanas.

\subsection{POUCOS TERMINAM BEM}

"Começar bem é muito importante, mas terminar bem ainda é muito, muito melhor," diz o Pr. Ary Veloso na entrevista feita por Rodolfo Montosa ${ }^{5}$ sobre Sucessão Pastoral.

Começar bem o ministério parece ser relativamente fácil. O que estudos, pesquisas e estatísticas indicam, é que bem mais difícil é terminar bem, tanto como ministro evangélico, quanto como pessoa. Dr. J. Robert Clinton, professor de liderança no Seminário Fuller, realizou estudos abrangentes sobre líderes na Bíblia e nas comunidades cristãs da atualidade. Segundo WONG, suas descobertas são bastante perturbadoras: "poucos líderes terminam bem" (Wong, 2006, p;18).

Em seu levantamento constata que menos de 30\% dos líderes na Bíblia terminaram bem, o que equivale a dizer que dois de cada três líderes não finalizaram bem sua carreira. Observando o fim da vida de vinte e quatro reis em Israel e Judá, chama atenção o fato de que apenas seis terminaram bem. Não é necessário ressaltar que um bom número deles já começou mal.

\footnotetext{
${ }^{3}$ Cf. vários textos bíblicos, como João 10.11 e 14.

${ }^{4}$ Verbete Poimen. O Novo Dicionário Internacional de Teologia do Novo Testamento. p.469.

${ }^{5}$ Disponível em www.institutojetro.com.br/lendoentrevista.asp?t=0\&a=139, acessado em 02/01/2008.
} 
Dificilmente alguém que começa mal vai terminar bem. Mas muitos começaram bem e, infelizmente, acabaram encerrando seu ministério e sua vida de forma desastrosa.

Segundo uma entrevista com o Pr. Edmund Spieker ${ }^{6}$, há estatísticas no âmbito norteamericano que revelam que de dez líderes apenas dois terminam bem. Diante desta realidade, o mesmo desenvolveu um ministério preocupado com a pessoa do pastor, realizando Clínicas Espirituais conhecidas como "Fermata", sob a tutela da CIM (Churches in Mission). Sua principal preocupação é auxiliar para que líderes terminem bem.

A pergunta desafiadora e urgente para a igreja e suas lideranças nestes dias é: Por que é tão difícil manter-se firme no curso, perseverar na caminhada e fazer uma boa conclusão do ministério iniciado? O que fazer ativamente para integrar e aumentar o rol daqueles que alcançam uma boa finalização? Como conseguir uma retrospectiva ministerial e de vida satisfatória, como aquela declarada convictamente pelo apóstolo Paulo: "Combati o bom combate, terminei a corrida, guardei a fé!“‘ (BÍBLIA, N.T. 2 Timóteo 4.7)?

\subsection{ESTRESSE MINISTERIAL E SOLIDÃO}

Segundo Roseli M. Kühnrich de Oliveira, o cientista Hans Seyle apresentou em 1936 pela primeira vez o conceito de estresse (OLIVEIRA, 2005, p.76). Partindo da fisiologia, ele definiu estresse como uma síndrome geral de adaptação onde o organismo reage a mudanças,

[...] e que se caracteriza por três fases adaptativas: $1^{\text {a }}$ ) reação de alarme, que corresponde ao estresse agudo, em que há liberação de adrenalina, $2^{\mathrm{a}}$ ) período de resistência, que corresponde ao estresse crônico, e $3^{a}$ ), chamada de exaustão, quando pode ocorrer a falência orgânica múltipla (OLIVEIRA, 2005, p.76).

A palavra estresse é derivada do latim, e agregou várias significações, entre elas: adversidade, aflição e, mais recentemente, pressão ou esforço. Estresse "é o estado que se caracteriza por um conjunto de reações psicofisiológicas do organismo a situações que desencadeiam tensão"?

Todas as pessoas sofrem algum tipo de estresse, seja qual for o tipo de atividade, mas quando ele se torna grave, resulta em sérias enfermidades físicas e emocionais, ressalta Martin Claret, citado por Oliveira (LUTZER, 2000, p.76). O estresse é considerado o "mal do século"

\footnotetext{
${ }^{6}$ SPIEKER, Edmund. As crises pastorais e a estratégia da Clínica Espiritual Fermata. Entrevista realizada em 07/12/2007, em Curitiba, PR.

${ }^{7}$ Verbete Estresse. Dicionário Houaiss da Língua Portuguesa. p.1264.
} 
e atinge as pessoas indistintamente. Assim os pastores não estão isentos nem imunes ao mesmo.

Conforme José Cássio Martins, citado por Oliveira, o estresse não precisa ser necessariamente negativo. Defende que o estresse pode ser um convite para "nos acertarmos na agenda de Deus", aprendendo com o estresse (LUTZER, 2000, p.77).

A solidão parece ser um dos grandes perigos que ameaçam constantemente os cuidadores pastorais. Erwin Lutzer, pastor da Moody Memorial Church, em Chicago, EUA, concorda que "o pastor, muitas vezes, está sozinho em suas lutas. Enquanto os membros podem falar abertamente com ele sobre os seus problemas, a recíproca não é verdadeira" (LUTZER, 2000, p.78). Com considerável freqüência pastores se queixam de não terem ninguém com quem conversar. A pesquisa com os pastores menonitas revela que um número representativo apontou a falta de um amigo ou de alguém com quem possa compartilhar suas dores e dúvidas como sendo uma das suas maiores faltas em seus ministérios.

A igreja e a comunidade em geral não imaginam nem suspeitam quanto um pastor, muitas vezes, se sente só, não tendo com quem desabafar ou receber orientação pessoal e ministerial.

\subsection{TENTAÇÕES E VULNERABILIDADE}

Ao mesmo tempo que o pastor é um cuidador que lida com dores alheias, é uma pessoa exposta ao sofrimento. Até sugeriu-se, já há algum tempo, uma nova grafia: cuida-dor - aquele que cuida da dor.

Na categoria dos perigos, o cuidador pastoral encontra armadilhas em várias tentações, comuns ao ser humano. Muitas vezes não considerado, sua vulnerabilidade pode atingir níveis de alto risco.

Jaime Kemp alerta:

Os pastores, aqueles que tem a missão de orientar, equipar, socorrer o rebanho, também correm perigo [...] São muitos os que tem caído vencidos pelo cansaço, pelo desânimo e pelo desespero, à beira das estradas. Outros, estão desistindo do ministério por fracassos morais e familiares, e ainda há os que se cansaram de serem abusados financeiramente por igrejas que não os valorizam, em termos concretos (KEMP, 1996, p.9).

O Pr. Eros Pasquini Jr. afirma que "em questão de pureza, não existe campo neutro; ou está seguro ou é minado". Para Pasquini há quatro grandes campos minados, que ameaçam 
ardilosamente os agentes pastorais: a sutileza do orgulho, a embriaguez do poder, a mania do dinheiro e a cobiça sexual (PASQUINI, 1996, p.30-32).

Como principais armadilhas inimigas que conduzem aos campos minados podem ser apontados os seguintes: 1) os ataques de surpresa, em momentos de descuido com a vigilância; 2) a inerente natureza carnal que continua acompanhando o pastor como uma oportuna plataforma de desembarque para as tropas inimigas e 3) o ambiente mundano e sufocante no qual o cuidador pastoral está inserido, que exerce forte influência e pressão constante, procurando seduzir para atitudes e atos ilícitos (PASQUINI, 1996, p.31).

Para o Pr. Edmund Spieker há, além destas tentações clássicas que incomodam os cuidadores pastorais, pelo menos mais duas, que merecem muita atenção: as questões familiares do próprio pastor e a ameaça da estagnação espiritual. ${ }^{8}$

Segundo Marshall Shelley, citado por Lutzer, "por um lado, os pastores são humanos. Pecam diariamente. Por outro lado, dedicam-se a uma profissão na qual caráter é fundamental. São chamados para liderar, ensinar e ser modelos de uma habilidade não técnica, mas de vida. Quando os pastores caem, podem ferir muitas pessoas" (LUTZER, 2000, p.146).

\subsection{SOBRECARGA E ESGOTAMENTO}

Enquanto o estresse é caracterizado por excesso de envolvimento e participação, o esgotamento é caracterizado pelo afastamento e pela perda de sentido e de esperança. Independente do que a pessoa faça, as recompensas parecem pequenas demais.

Pastores e pastoras são especialmente vulneráveis ao esgotamento. Podem ser vítimas da síndrome de Burnout. ${ }^{9}$ Conforme Oliveira, esta doença também é chamada de síndrome da desistência, de exaustão ou de consumição. O termo começou a ser usado nos anos 70, por Freudenberger. Cezar Cozzatti, psiquiatra e médico da delegacia do trabalho, em Porto Alegre, define Burnout como "desgaste ocupacional dos cuidadores" (OLIVEIRA, 2005, p. 80-81).

Erwin Lutzer, escreve em seu livro "De pastor para pastor - Respostas concretas para os problemas e desafios do ministério":

\footnotetext{
${ }^{8}$ SPIEKER, Edmund. As crises pastorais e a estratégia da Clínica Espiritual Fermata. Entrevista realizada em 07/12/2007.

${ }^{9}$ Nota: Burnout: Burn signifca queima e out, exterior, na língua inglesa. Associado a uma síndrome, significa esgotamento decorrente do desgaste profissional
} 
Espera-se que sejamos bons pregadores, conselheiros e administradores; temos de ter noção de publicidade e a habilidade de amar as pessoas e demonstrar isso nas relações humanas. Quando essas responsabilidades não são acompanhadas de recompensas, as pressões de tais expectativas podem levar a um senso de inutilidade e desespero. Como as pessoas procuram o pastor para receber e não para dar, os recursos emocionais dele podem se exaurir rapidamente (OLIVEIRA, 2005, p. 78).

A Síndrome de Burnout é freqüentemente confundida com o estresse, mas é mais intenso e de consequências mais drásticas para a pessoa acometida. Embora pastores contem com a espiritualidade como um fator de saúde, o ministério impinge um desgaste em função das demandas constantes e variadas, fazendo uma correlação entre a exaustão emocional, física e espiritual.

Oliveira destaca que o esgotamento que atinge os cuidadores pastorais provavelmente acontece em número bem maior do que em geral se supõe. Ressalta também que o descuido ou a falta de cuidado não são exatamente um ato consciente, mas origina-se da impossibilidade de reagir às demandas. Pode até haver certa passividade diante das exigências desmedidas por parte da igreja ou comunidade (OLIVEIRA, 2005, p. 82-83).

Numa entrevista o Prof. Dr. Gottfried Brakemeier declarou para Oliveira que "pregar o que não se crê é um dos maiores fatores de esgotamento" (OLIVEIRA, 2005, p. 83). Parece haver, para um número considerável de pastores, um cristianismo retórico de púlpito e outro, do dia a dia - menos triunfante, menos poderoso.

Infelizmente muitos cuidadores, quanto mais correm, menos energia tem para terminar bem. Eros Pasquini Jr. aconselha a não trabalhar até a exaustão, porque ela deixa a pessoa emocionalmente vulnerável. Denuncia que a nossa cultura nos impulsiona na direção de sermos polivalentes. Lembra que se o futebol fosse nossa ilustração, o pastor seria o jogador completo: de goleiro a ponta-esquerda, jogando em todas as posições, além de buscar a bola quando chutada fora de campo. O sentimento de imprescindibilidade e de urgência profissional move e impulsiona muitos pastores. Não raro, porque não conseguem passar sem um elogio ou uma massagem no seu ego (OLIVEIRA, 2005, p. 33).

Conforme Dr. David Congo, da Clínica de Aconselhamento Familiar de H. Norman Wright, citado por Lutzer, são candidatos ao esgotamento pessoas com uma ou mais das seguintes características: “1) grande necessidade de aprovação; 2) viciadas em trabalho; 3) vítimas passivas e sem opinião própria e 4), com “complexo de messias" (LUTZER, 2000, p.79). 


\subsection{POSSIBILIDADES DE O CUIDADOR SER FERIDO E MAGOADO}

Muitos pastores recebem seus ferimentos e suas mágoas justamente daqueles a quem estão dedicando seu cuidado. A igreja, muitas vezes, tem machucado seus líderes e atingido seus cuidadores com flechas envenenadas de palavras e atitudes inconvenientes.

Como um cuidador ferido poderá continuar cuidando devidamente de outros feridos? Que chances alguém magoado e amargurado tem em auxiliar pessoas que estão na mesma condição?

Os autores London Jr. e Wiseman destacam em seu livro Seu pastor uma espécie em extinção que

a crítica fere os pastores, um fato que muitos líderes acham difícil de entender. Eles questionam por que os ministros não podem ser mais resistentes [...] O que parece ser super-sensibilidade desenvolve-se em ministros porque seus compromissos os conectam completamente com o que acontece na igreja. Muitas vezes eles vêem a si mesmos como pára-raios organizacionais que atraem aprovação ou desaprovação. Desta forma, a crítica ao ministro, muitas vezes soa como uma repulsa ou insulto (LONDON, WISEMAN, 1998, p.62).

Muitas feridas podem ser resultantes de expectativas frustradas. Esperar demais das pessoas e ser decepcionado, provoca mágoa e raiva. $\mathrm{O}$ acúmulo de ira gera ódio e pode consumir toda a energia de uma pessoa, deixando-a até com sintomas de doença. Há pastores nesta condição. Com relacionamentos e suas emoções abalados, estes pastores dificilmente conseguirão restaurá-los sozinhos e sem o auxílio de um cuidador empático.

Não é incomum encontrar pastores feridos por terem tropeçado na área moral e que tem dificuldade para encontrar o caminho do retorno, pois são mais alvos de condenação do que de mãos estendidas cheias de misericórdia e compaixão. Não é uma questão de amenizar o pecado, mas reforçar o exercício do amor e da aplicação da graça, ajudando a curar e recuperar o cuidador ferido.

Um soldado ferido tem dificuldade em continuar combatendo na linha de frente. Suas chances de vencer são mínimas. Sua maior necessidade é ser tratado e cuidado por alguém. Sua aptidão para continuar a luta depende, nesta circunstância, em que grau ele já foi recuperado e restaurado. Sua continuidade na relação de ajuda está diretamente atrelada à sua restauração.

A quem o pastor pode recorrer quando está ferido e machucado? Há alguém que se dispõe a socorrê-lo? 
Mantendo esta figura, há um dizer bastante conhecido que diz "a igreja talvez é o único exército que abandona seus soldados feridos". Se for verdade, é uma denúncia gravíssima e, ao mesmo tempo, muito preocupante, tendo em vista os agentes pastorais feridos.

Em caso de doença, um médico pode necessitar de outro profissional da medicina. $\mathrm{Na}$ qualidade de pastor ferido e magoado, este necessita também de outro cuidador para sua alma.

A crise aumenta quando o pastor se sente condenado a atravessar o deserto sozinho, sem qualquer oásis à vista nem outro viajante, pronto para ajudá-lo. É fácil sugerir evasivamente: "cuidou de outros, que cuide agora de si”. Há situações em que o cuidado de si é impossível e infrutífero. Os ferimentos são grandes e profundos demais. Se não houver socorro de origem externa, não haverá esperança para o pastor ferido.

\subsection{AUSÊNCIA DE PRESTAÇÃO DE CONTAS DA VIDA PESSOAL}

Os membros das igrejas têm alguém (pelo menos deveriam ter) que os orienta, acompanha, alerta, exorta, cobra e corrige. E o próprio pastor? Quem é seu confidente? A quem ele presta contas sobre sua vida pessoal e familiar? Quem monitora sua trajetória espiritual?

Jorge Atiência sublinha:

\footnotetext{
O chamado a apascentar implica riscos, conflitos e às vezes fracassos. Necessitamos toda a graça e o poder de Deus para pastorear outros. E nós também precisamos ser pastoreados. Com frequiência, aqueles que ocupam posições de liderança sentem falta de alguém na sua vida que lhes sirva de pastor. Quando existe este vazio, há ocasiões em que os pastores se sentem limitados em sua tarefa de pastorear outras pessoas [...] estar sempre conscientes de que nós também somos ovelhas e precisamos ser pastoreados por outros (ATIENCIA, 2000, p.82).
}

Edison Queirós escreve em seu livro Transparência no Ministério: "A tendência da maioria das pessoas (incluindo-se os pastores) é fugir da prestação de contas, com a idéia de que não precisa fazer isso. O sentimento de rebelião e independência é inerente ao ser humano. Porém, poucos descobriram que a verdadeira liberdade está em prestar contas a outros, porque a prática traz paz à consciência" (QUEIRÓS, 1998, p. 214).

London e Wiseman asseveram que 


\begin{abstract}
"todo pastor precisa de um amigo absolutamente digno de confiança a quem ele, voluntariamente, presta contas de sua vida espiritual. Idealmente um amigo espiritual questiona livremente o pastor acerca de suas motivações, de seu casamento e de seu ministério. Deve-se conceder permissão ao amigo espiritual para questionar inclusive o seu relacionamento com Deus. O pastor precisa de um amigo espiritual que o ame ao ponto de ser carinhoso, e ao mesmo tempo firme. Idealmente, o amigo espiritual deveria se dispor a ouvir redentivamente as suas dores, afirmar seus pontos fortes e exortá-lo à autenticidade. Deve saber quando dar tapinhas no ombro do pastor e quando chutá-lo no traseiro (LONDON, WISEMAN, 1996, p. 195).
\end{abstract}

Stu Weber afirma: "Em algum lugar nós aceitamos uma idéia errada sobre força e independência. Parece que nós achamos que eram sinais de maturidade. Nós fomos levados a acreditar na mentira de que quando eu crescer para ser um homem verdadeiro, não vou precisar de mais ninguém. Nada poderia ser mais enganoso" (WEBER, 1997, p. 216).

Infelizmente, muitas vezes pastores aceitam e se submetem ao postulado de que verdadeiros e respeitáveis pastores carregam os fardos e as dificuldades sozinhos. Mas isto é um mito que tem prejudicado e lesado muito pastores, fazendo-os sucumbir sob seu peso, que carregam solitários e silenciosamente, afetando inclusive as suas igrejas.

\title{
1.8 DESCUIDO E NEGLIGÊNCIA NA VIDA PESSOAL E FAMILIAR
}

Os pastores facilmente trabalham em ritmo frenético e não percebem que estão deixando de lado os cuidados básicos consigo mesmos, como alimentação, sono, saúde, equilíbrio emocional, descanso, lazer. A razão é que eles não se dão conta das próprias necessidades. Por vezes, é a própria espiritualização, característica nos agentes pastorais, que embaça a visão para o devido cuidado consigo mesmo. Para alguns não é apenas descuido, mas verdadeiro descaso com as questões mais elementares, que geram equilíbrio e saúde integral. Alguns pastores até relatam que se sentem culpados quando dão passos para cuidarem mais de si, parecendo serem egoístas se procurarem seu próprio bem-estar, quando deviam estar cuidando dos outros.

Oliveira é categórica, quando destaca que "cuidado de si mesmo é fundamental para quem trabalha nas relações de ajuda, uma vez que o cuidador é parte do processo, interagindo no sistema de cuidados a partir de si mesmo como pessoa" (OLIVEIRA, 2005, p. 133).

Cita, apropriadamente, a orientação que São Barromeu dava aos sacerdotes: "Não descuides por causa disso o cuidado de ti mesmo, e não te dês aos outros até ao ponto de não restar nada de ti, para ti próprio. Certamente, deves ter presente a recordação das almas de quem és pastor, mas não te esqueças de ti mesmo" (OLIVEIRA, 2005, p.112). 
O pastor facilmente pode cumprir o trabalho pastoral aparentemente bem, sendo um hipócrita entre teoria ministerial e prática pessoal, deixando sua vida interior negligenciada e descuidada. Este fato é atestado por Eugene H. Peterson, citado por London Jr. e Wiseman,

Três atos pastorais - orar, ler a Escritura e dar direção espiritual - são tão básicos, tão críticos, que estruturam todas as demais coisas do ministério. Além de serem básicos, estes três atos são silenciosos e feitos, na maioria das vezes, fora das luzes do palco do ministério público. E por não chamarem atenção para si mesmos, são muitas vezes negligenciados... Por conta de quase nunca notarem se fazemos estas coisas ou não, e somente ocasionalmente, requisitarem que as façamos, estes verdadeiros atos pastorais sofrem negligência generalizada (Apud LONDON, WISEMAN, 1996, p.188).

O apóstolo Paulo já recomendava ao seu discípulo e mentoreado Timóteo: Tem cuidado de ti mesmo e da doutrina. Continua nestes deveres; porque, fazendo assim, salvarás tanto a ti mesmo como aos teus ouvintes (BÍBLIA, N.T. 1 Tim 4.16).

Referindo-se à preocupação quanto ao cuidado de si mesmo, o apóstolo declarou sobre seu próprio empenho: Assim corro também eu, não sem meta; assim luto, não como desferindo golpes no ar. Mas esmurro o meu corpo e o reduzo à escravidão, para que, tendo pregado a outros, não venha eu mesmo a ser desqualificado (BÍBLIA, N.T. 1 Cor 9.26-27).

"Cuidar de si mesmo é um aspecto importante na tarefa de quem pastoreia. Em essência, isto significa que nenhum dia da minha vida posso esquecer que eu mesmo sou 'ovelha'”, afirma Jorge Atiência (ATIENCIA, 2000, p. 75).

Não faltam pastores que descuidam da sua vida conjugal e familiar por estarem envolvidos demasiadamente no cuidado com os outros. Não são poucos os familiares dos cuidadores que reclamam que estes, aparentemente, têm maior facilidade em cuidar dos outros em vez dos seus, dentro da própria casa.

Oliveira cita José Cássio Martins, que trabalha no apoio a pastores:

A família do pastor é a primeira que sofre com ele. A igreja tem o pastor, mas a sua família nem sempre o tem. Ele tende a ser mais disponível para igreja do que para a sua própria família. Isto é uma característica da nossa herança teológica e espiritual. [...] É muito bom e necessário sentir-se vocacionado, mas a excessiva sacralização da vocação pode fazer com que o pastor perca o senso de si mesmo, tornando-se uma "propriedade da sua vocação". Por isso, ocorre em muitos casos a perda da individualidade e da identidade, para não dizer da sanidade (OLIVEIRA, 2005, p. 92-93). 


\section{DESAFIOS NO CUIDADO DOS AGENTES PASTORAIS}

Há uma necessidade urgente de se importar com o cuidado daqueles que cuidam. Os desafios são nada pequenos. Há algumas questões que precisam ser revistas, tanto pelos que recebem, como pelos que oferecem cuidados.

\subsection{RESULTADOS DA PESQUISA DE CAMPO SOBRE O CUIDADO DE PASTORES}

Para um levantamento da situação do cuidado dado aos pastores nas igrejas evangélicas menonitas brasileiras, e o cuidado que estes proporcionam a si mesmos, foram distribuídos 100 questionários e obtidas 81 respostas. Foram pesquisados pastores e pastoras de três denominações Menonitas: a COBIM - Convenção Brasileira das Igrejas Irmãos Menonitas, a AEM - Aliança Evangélica Menonita e a AIMB - Associação das Igrejas Menonitas do Brasil. A pesquisa foi realizada entre julho e outubro de 2007.

Os resultados apresentados a seguir são bastante representativos, uma vez que acima de $60 \%$ do contingente de pastores e pastoras destas três denominações participou da pesquisa.

A pesquisa teve o intuito de permitir pastores e pastoras expressarem e manifestarem sua percepção do cuidado que recebem como cuidadores de outros, além de informarem aspectos a respeito do auto-cuidado.

A tabulação dos dados obtidos foi feita em planilha e depois representada graficamente em quadros e tabelas. Para fins de análise e comentário, a sequência dos dados não é citada em ordem cronológica conforme encontradas no questionário. 
GRÁFICO 1 - NÚMERO DE PASTORES E PASTORAS POR DENOMINAÇÃO QUE RESPONDERAM À PESQUISA

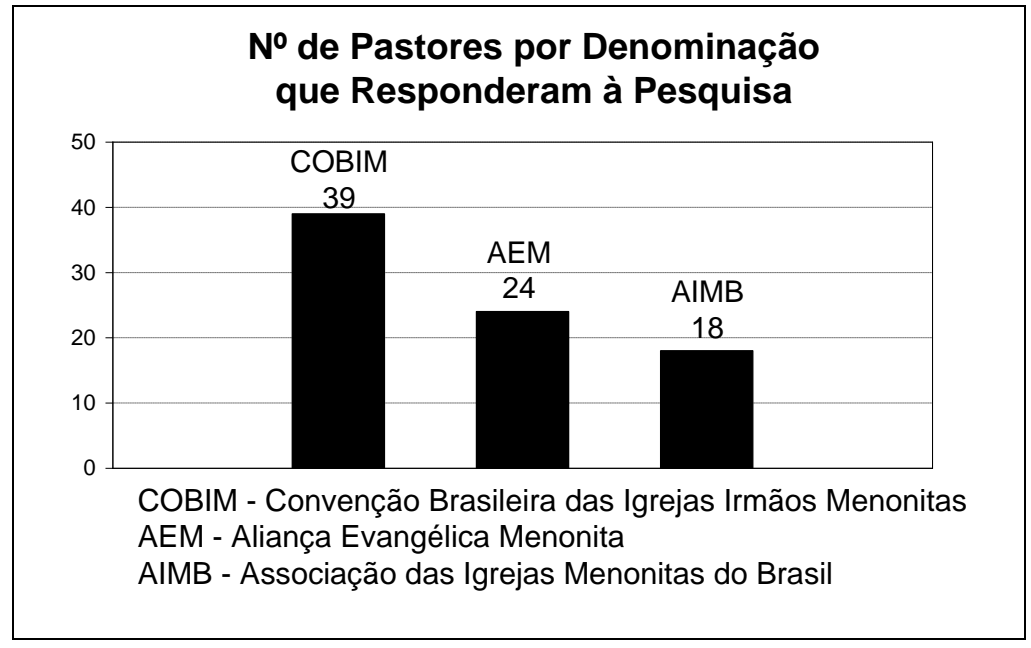

Das 81 respostas, 39 são de pastores da COBIM, 24 da AEM e 18 da AIMB.

\section{GRÁFICO 2 - NÚMERO DE PASTORES POR FAIXA ETÁRIA}

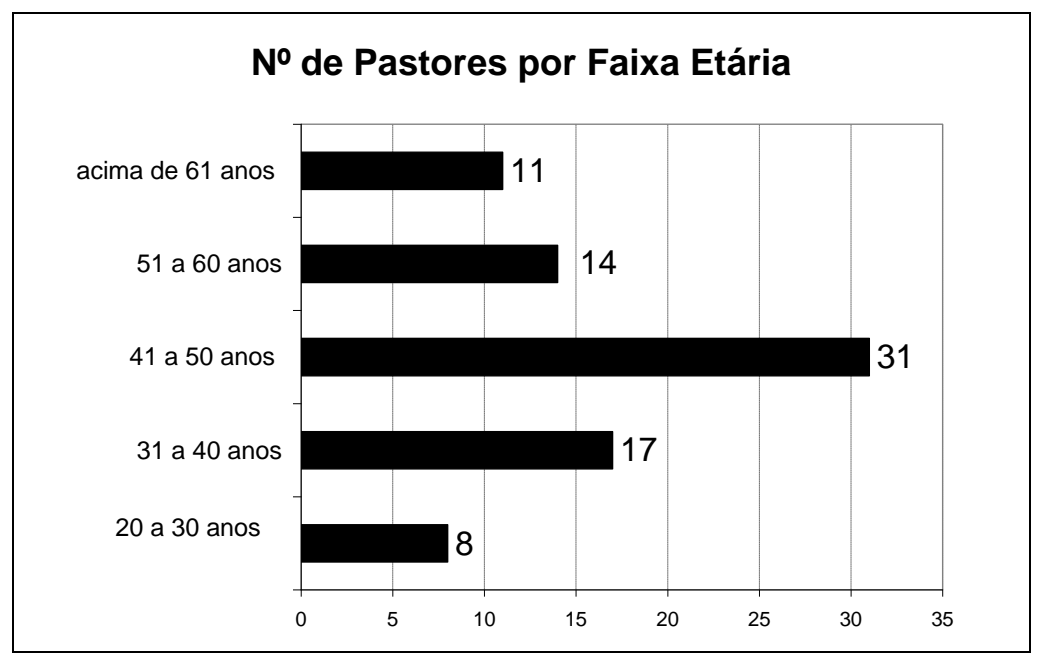

Observa-se neste gráfico que a maioria dos pesquisados (31) encontra-se na faixa etária entre 41 e 50 anos. Vinte e cinco dos pastores tem idade abaixo de 40 anos. 


\section{GRÁFICO 3 - O SEXO DOS PASTORES QUE RESPONDERAM À PESQUISA}

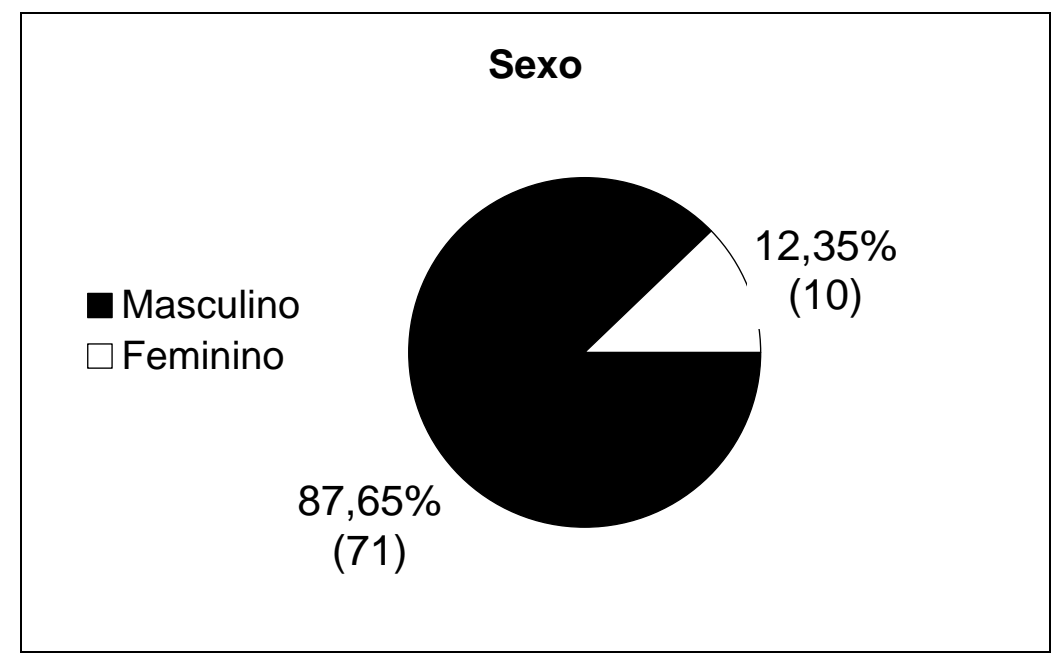

O número de pastoras é reduzido, representando apenas $12,3 \%$ dos pesquisados. A COBIM, a maior das denominações, não aprova a ordenação de mulheres para o ministério pastoral. Na AIMB há considerável resistência ao exercício do ministério feminino na função pastoral e para a AEM a questão é pacífica e pastoras são, inclusive, bastante aclamadas.

\section{GRÁFICO 4 - ESTADO CIVIL DOS PASTORES E PASTORAS QUE RESPONDERAM À} PESQUISA

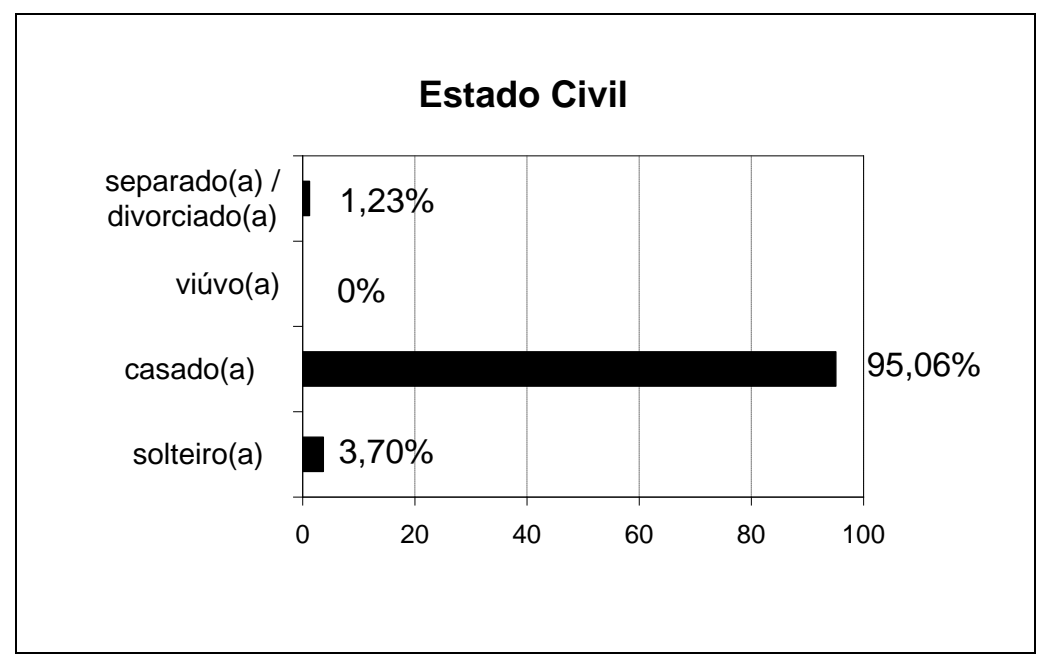

Apenas 3,7\% são solteiros e 1,2\% separados e/ou divorciados. Entre os pesquisados não houve viúvos. A grande maioria $(95,1 \%)$ é casada. 
GRÁFICO 5 - ESTADOS DE ATUAÇÃO MINISTERIAL DOS(AS) PASTORES(AS) QUE RESPONDERAM À PESQUISA

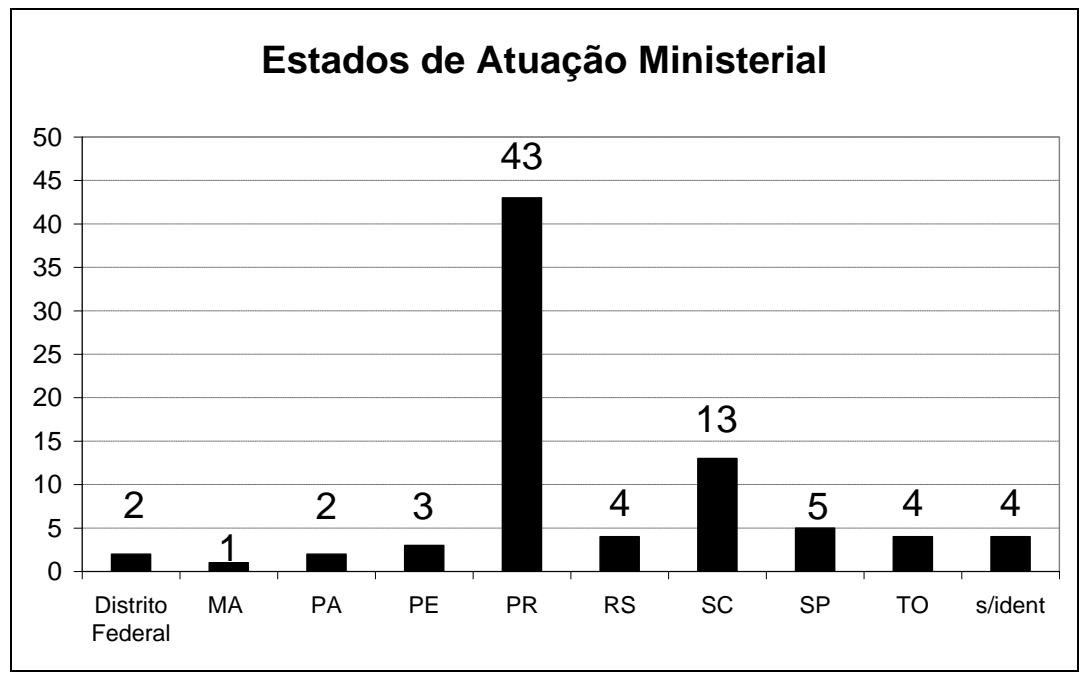

O maior número dos pesquisados (43) desenvolve seu ministério pastoral no Estado do Paraná. Em segundo lugar está Santa Catarina. Por alguma razão pessoal, quatro pastores ou pastoras não identificaram seu Estado.

\section{GRÁFICO 6 - TEMPO DE MINISTÉRIO PASTORAL DOS RESPONDENTES}

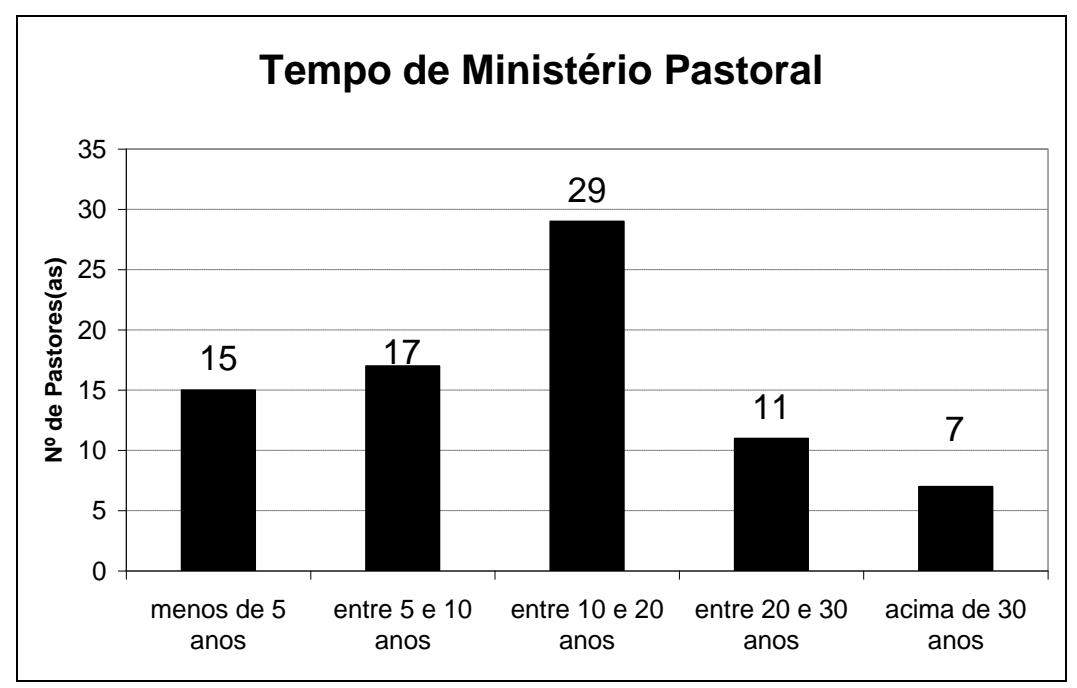

Vinte e nove dos pesquisados já estão entre 10 e 20 anos no exercício do ministério pastoral, indicando considerável tempo de experiência nas atividades pastorais. Somando aqueles que estão a menos de dez anos na atividade, foram identificados 32 pastores. 


\section{GRÁFICO 7 - COMO OS RESPONDENTES EXERCEM O SEU MINISTÉRIO}

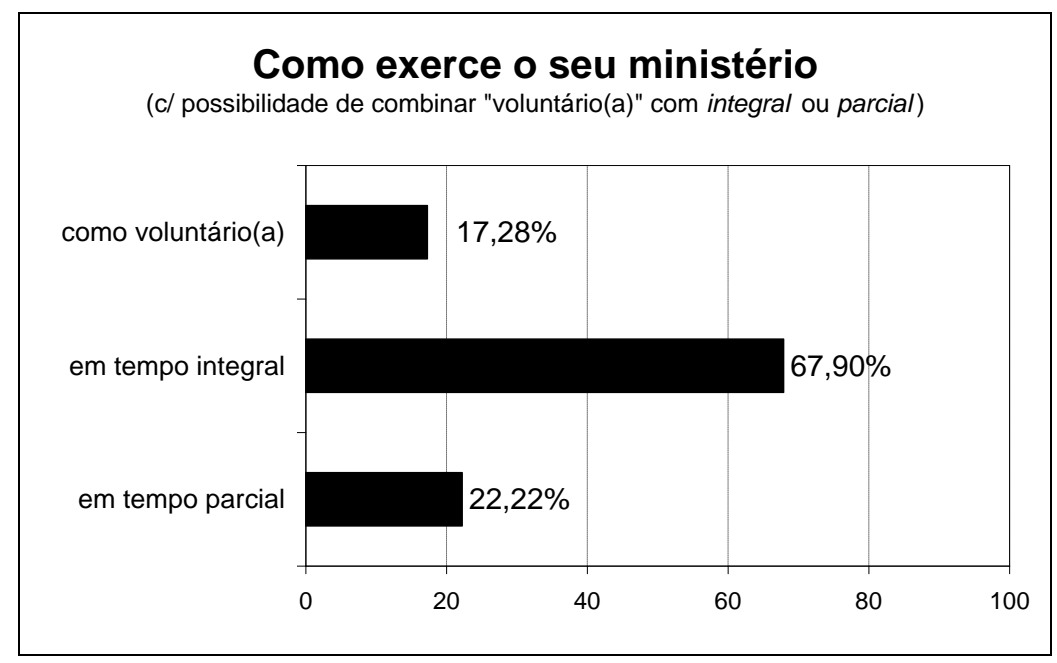

O gráfico revela que 22,2\% dos pastores e das pastoras exercem seu ministério pastoral em tempo parcial, dedicando parte do seu tempo à outras atividades, em geral para ajudar no orçamento familiar. Uma considerável porcentagem $(17,3 \%)$ está servindo como voluntário, sem remuneração fixa.

\section{GRÁFICO 8 - MOTIVO ALEGADO PELOS RESPONDENTES DA RAZÃO DE SER}

\section{PASTOR OU PASTORA}

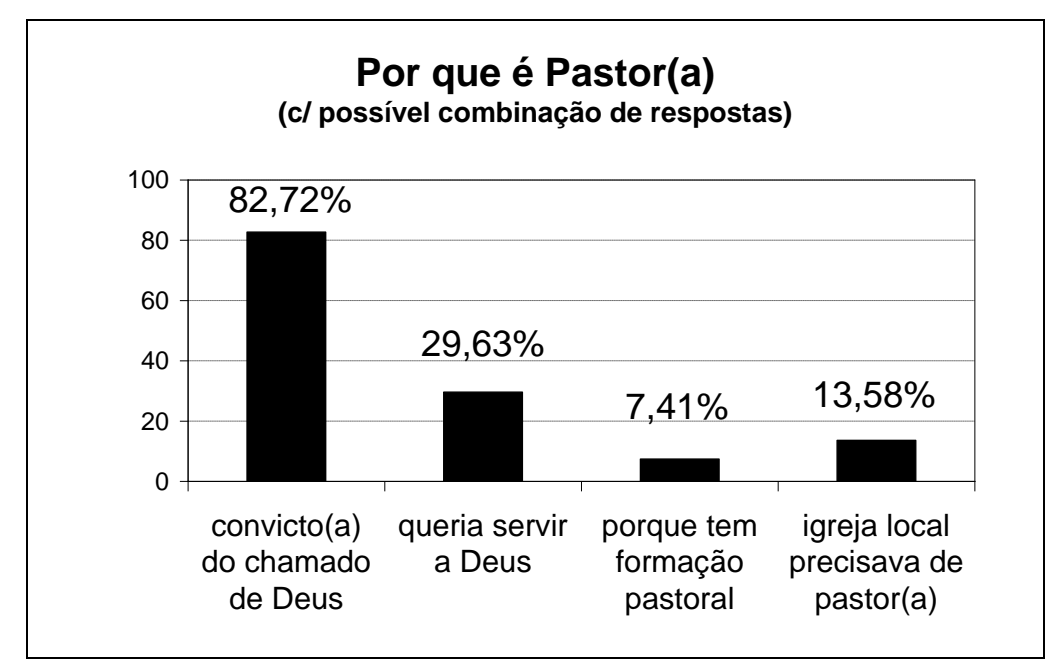

A convicção do chamado de Deus para o envolvimento no trabalho pastoral representa $82,7 \%$ dos casos. Nem todos os pastores e pastoras $(12,3 \%)$ tem certeza a respeito do seu 
chamado específico para a atividade pastoral. A necessidade local levou 13,6\% a abraçarem a causa, lembrando que esta resposta pode estar relacionada com uma das anteriores.

GRÁFICO 9 - O SENTIMENTO DO RESPONDENTE NA CONDIÇÃO DE SER PASTOR OU PASTORA

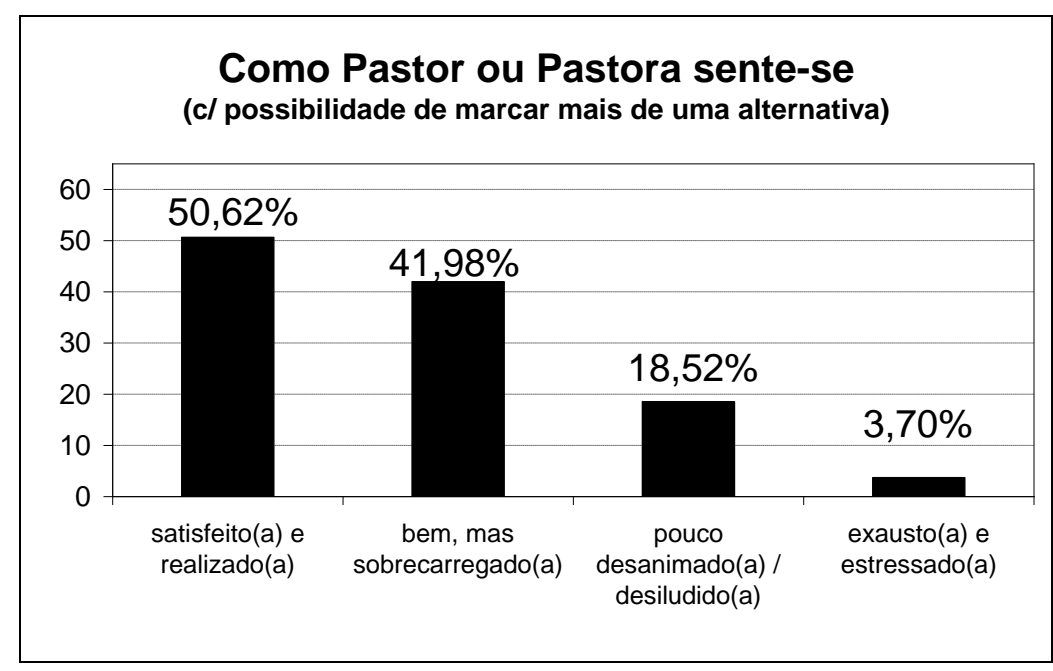

Este gráfico revela como os pastores e as pastoras pesquisados se sentem na maior parte do tempo, indicando que 50,6\% se consideram satisfeitos e realizados.

Atenção chamam os 41,9\%, que responderam que estão bem, mas sobrecarregados. Merecedores de atenção maior são os 18,5\%, que se sentem pouco desanimados e desiludidos. Este contingente já deve ser alvo de providências em como lidar com os fatores geradores de desânimo. Em estado de alerta máximo estão 3,7\%, que reconhecem estarem exaustos e estressados. 
GRÁFICO 10 - AVALIAÇÃO DAS IGREJAS NA PERSPECTIVA DOS PASTORES E DAS PASTORAS RESPONDENTES

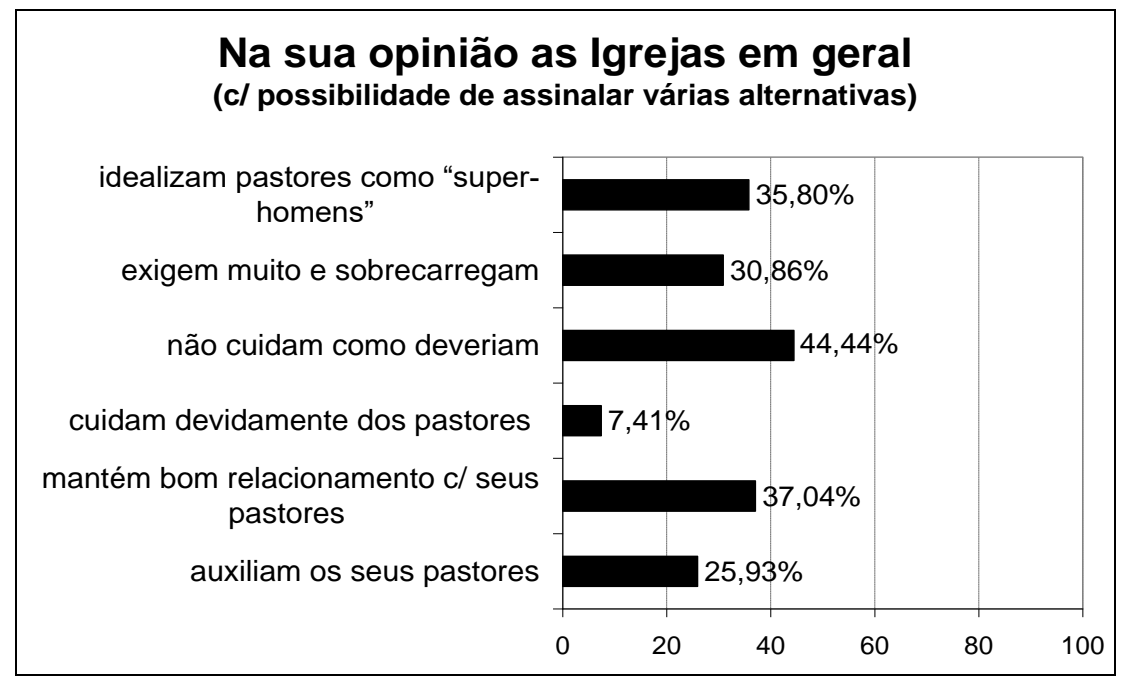

A percepção que os pastores e as pastoras pesquisados têm das igrejas, é que elas não cuidam como devem $(44,4 \%)$, são muito exigentes $(30,9 \%)$, além de idealizarem os pastores como super-homens ou como super-mulheres $(35,8 \%)$.

\section{GRÁFICO 11 - LEVANTAMENTO ENTRE OS RESPONDENTES DO CUIDADO RECEBIDO E DADO}

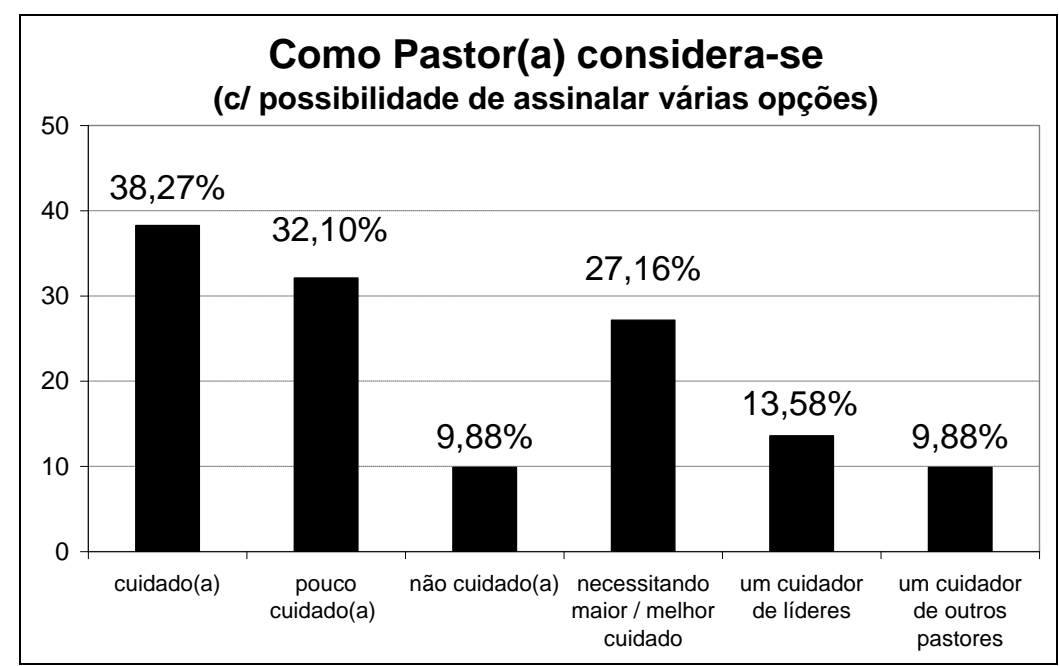

A pesquisa revela que $32,1 \%$ dos pastores e das pastoras consideram-se pouco cuidados e 27,2\% declararam necessitar de maior e melhor cuidado. Para os que não são cuidados há um índice de quase 10\% (9,9\%). Apenas 13,6\% se considera "um cuidador de líderes" e 9,9\% "um cuidador de outros pastores". 


\section{TABELA 1 - CUIDADOS QUE OS REPONDENTES TÊM CONSIGO MESMO}

\begin{tabular}{ccc}
\hline ÀREA & $\mathbf{N}^{\mathbf{0}}$ de Respostas & $\%$ \\
\hline sono & 53 & 65,43 \\
alimentação & 60 & 74,07 \\
lazer & 36 & 44,44 \\
exercício físico & 30 & 37,04 \\
equilíbrio emocional & 48 & 59,26 \\
saúde mental & 39 & 48,15 \\
saúde física & 41 & 50,62 \\
férias & 38 & 46,91 \\
dia de folga semanal & 28 & 34,57 \\
\hline
\end{tabular}

NOTA: Foi dada opção de assinalar várias áreas onde tem dispensado cuidado

A tabela de dados sobre o cuidado consigo mesmo em relação a várias áreas denuncia que os pesquisados são bastante negligentes com seu equilíbrio pessoal. A alimentação recebe o melhor índice $(74,1 \%)$, seguido pelo sono, com $65,4 \%$. Apenas $46,9 \%$ tem conseguido cuidar adequadamente das férias e $34,6 \%$ do dia de folga semanal.

\section{GRÁFICO 12 - PERCEPÇÃO DOS RESPONDENTES SOBRE A ADMINISTRAÇÃO PESSOAL DO TEMPO}

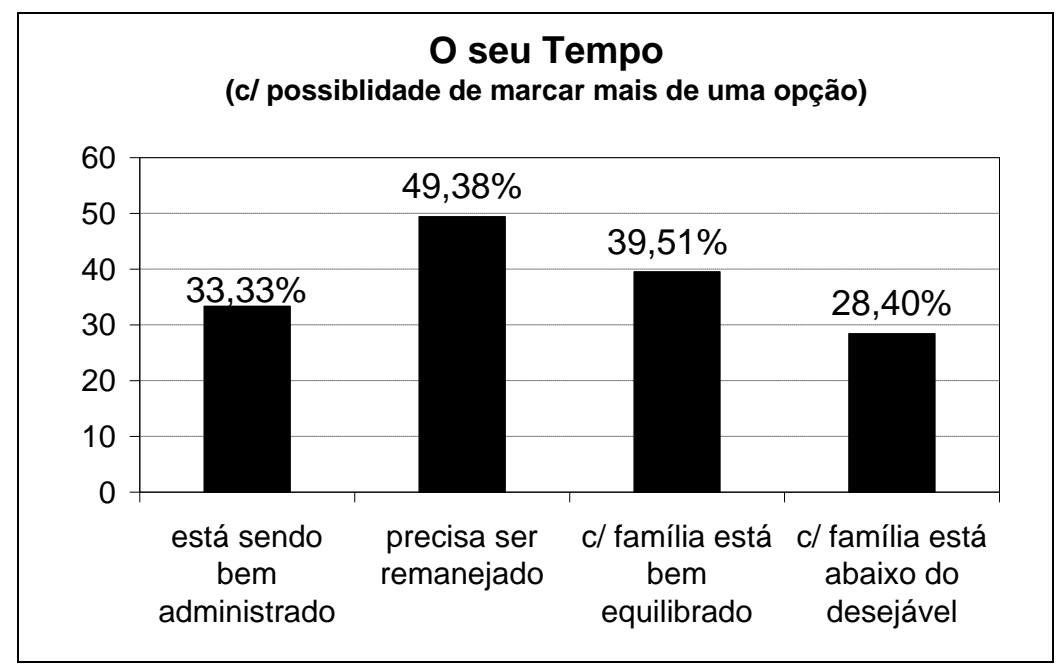

49,4\% dos pesquisados revelaram que o seu tempo precisa ser remanejado. $28,4 \%$ reconhecem que o tempo que passam ou dão para a família está abaixo do desejável. 


\section{TABELA 2 - DO QUE MAIS OS RESPONDENTES SENTEM FALTA COMO PASTOR} OU PASTORA

\begin{tabular}{lc}
\hline & $\begin{array}{c}\mathrm{N}^{\mathbf{o}} \text { de } \\
\text { respostas }\end{array}$ \\
\hline Alguém para compartilhar / amigo(s) / companheiro de jugo & 21 \\
Encontro com outros pastores (mais profundo) & 8 \\
Mentor / Discipulador / pastoreio & 15 \\
Melhor preparo / Treinamento / Estudo / Capacitação & 15 \\
Respeito, reconhecimento e confiança das ovelhas (e outros pastores) & 6 \\
Estabilidade financeira & 4 \\
Nenhuma falta indicada & 13 \\
\hline
\end{tabular}

Neste levantamento os pastores e as pastoras tiveram a oportunidade de enumerarem livremente três itens de que mais sentem falta como pastores e pastoras. Para o presente relatório foram considerados apenas itens que foram mencionados mais de quatro vezes. A necessidade de um amigo ou alguém para compartilhar foi apontado por 21 pesquisados. Quinze expressaram a falta de um mentor ou discipulador ou pastor pessoal, assim como também quinze sentem falta de melhor preparo, treinamento ou estudo, e capacitação.

\section{GRÁFICO 13 - RELACIONAMENTO DOS RESPONDENTES COM A AGENDA}

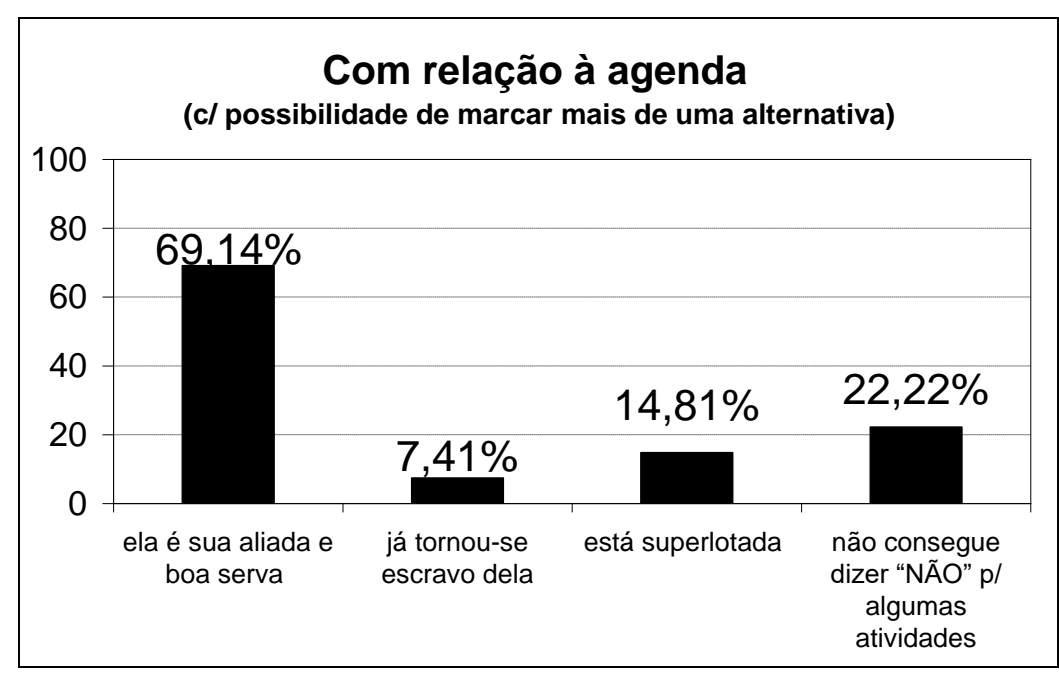

Neste gráfico $69,1 \%$ representam pastores e pastoras que vêem na agenda uma aliada e boa serva para os compromissos da tarefa pastoral e a vida pessoal. No entanto, $22,2 \%$ dos pesquisados admitem que tem dificuldade em afirmar um "NÃO" necessário diante de algumas atividades secundárias, enquanto $14,8 \%$ reclamam de uma agenda superlotada. 


\section{GRÁFICO 14 - A DISCIPLINA DEVOCIONAL DOS RESPONDENTES}

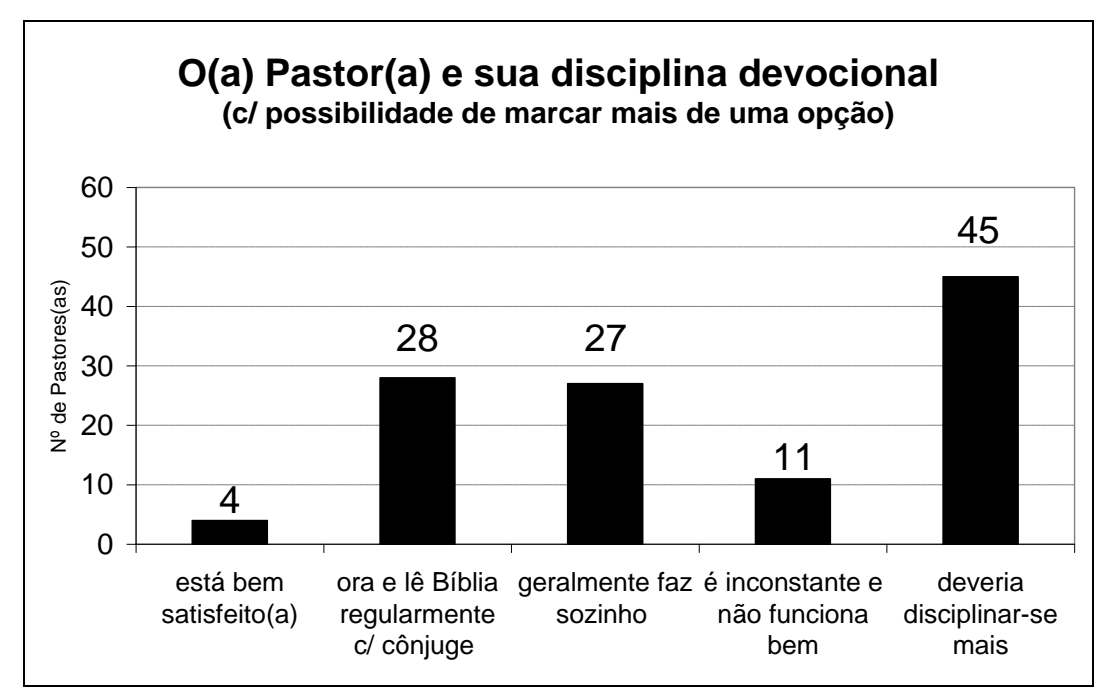

Perguntados referente a sua prática da disciplina devocional, 45 pesquisados admitem que deveriam disciplinar-se mais. Sendo que a grande maioria é casada $(95,0 \%$ conforme GRÁFICO 4), merece destaque o fato de que apenas 28 sinalizaram que oram e lêem a Bíblia regularmente com o seu cônjuge e 27 declaram fazê-lo geralmente sozinhos. A coluna representando os bem satisfeitos com sua vida devocional atingiu a baixa marca de 4 pesquisados.

\section{TABELA 3 - ATITUDE DIANTE DE DIFICULDADES PESSOAIS E MINISTERIAIS DOS RESPONDENTES}

\begin{tabular}{lcc}
\hline \multicolumn{1}{c}{ Diante de dificuldades pessoais } & & \\
\multicolumn{1}{c}{ e ministeriais } & $\mathbf{n}^{\mathbf{o}}$ respostas & $\boldsymbol{\%}$ \\
\hline costuma procurar um conselheiro & 31 & 38,27 \\
dificilmente procura outro pastor & 9 & 11,11 \\
é transparente para seu mentor & 16 & 19,75 \\
compartilha c/ líderes da sua equipe & 42 & 51,85 \\
conta com o ombro de um amigo(a) & 21 & 25,93 \\
divide a luta apenas com seu cônjuge & 29 & 35,80 \\
fica, quase sempre, sozinho c/ fardo & 16 & 19,75 \\
\hline
\end{tabular}

Questionados sobre a quem recorrem quando estão com dificuldades pessoais e ministeriais, $35,8 \%$ expressou dividir a luta apenas com o seu cônjuge e $19,7 \%$ afirmaram que ficam, quase sempre, sozinhos com o fardo. 
GRÁFICO 15 - POSICIONAMENTO DOS RESPONDENTES EM RELAÇÃO A TER UM CUIDADOR PESSOAL

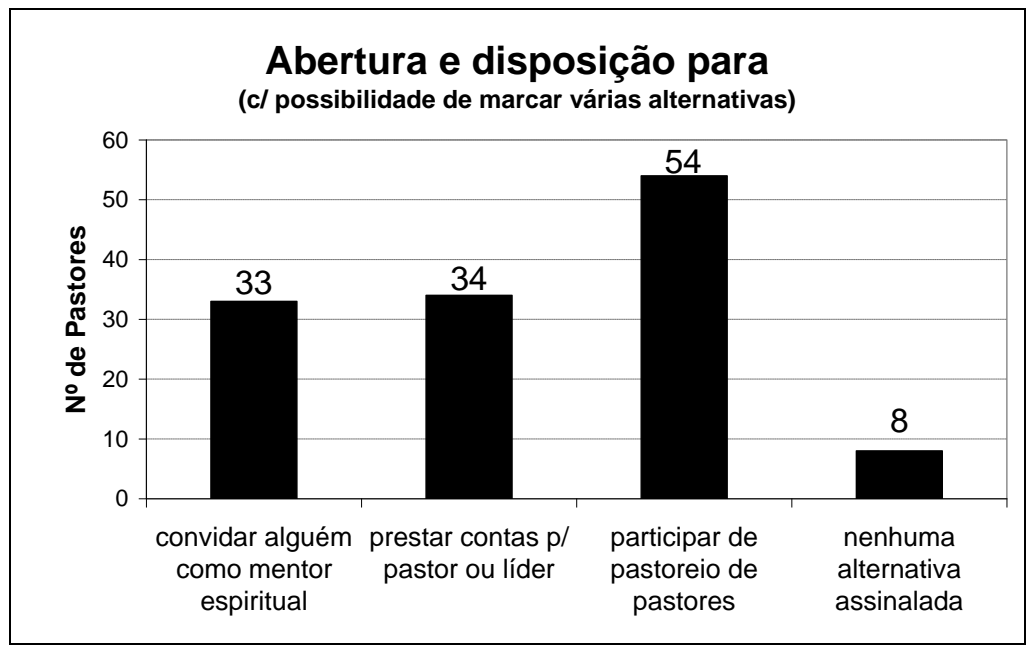

Solicitados a assinalarem a respeito da sua disposição quanto a ter ou encontrar um cuidador pessoal, 33 pesquisados demonstraram interesse em convidarem alguém como mentor, 34 expressaram que estão abertos para prestarem contas da vida pessoal e ministerial a outro pastor ou líder e 54 manifestaram disposição para participar de um grupo de pastoreio de pastores. Apenas 8 se abstiveram de qualquer pronunciamento, sendo que alguns anotaram que já desfrutam de um cuidado adequado e satisfatório.

\subsection{DESMISTIFICAÇÃO DO PASTOR SEMPRE VENCEDOR E PERFEITO}

Não tem como se negar que ao pastor é conferido uma posição de destaque. De acordo com a forma como muitas pessoas olham para um pastor, o mesmo se parece mais com um E.T. ${ }^{10}$ do que um humano, que tem um chamado divino para desenvolver e cumprir uma função de cuidado de outros iguais.

Esta tendência é evidenciada quando $35,8 \%$ dos pastores e pastoras pesquisados concordam que as pessoas e as igrejas em geral idealizam os pastores como super-homens e as pastoras como super-mulheres.

O seguinte texto descreve de forma sucinta como muitas vezes o ministério e a vida pastoral é percebida:

\footnotetext{
${ }^{10}$ Nota: E.T. é alusão a um filme americano, que tinha por nome E.T. the Extra-Terrestrial, e corresponde ao português "E.T., o extraterrestre".
} 
Ele sempre está pronto a atender qualquer pessoa. Não se limita a horários. De dia ou de noite, se o telefone toca ou alguém bate à porta, não mede esforços nem avalia circunstâncias. Mesmo que não o busquem, ele vai diligentemente à procura das pessoas, a fim de assisti-las em suas necessidades. Ouve lamentos, queixas, desabafos, confidências. Chora e ri, aconselha e ora. Conforta e ajuda a dissipar as sombras que toldam a existência. Estende a mão ou o cajado e liberta o que se acha perdido entre os espinhos da vida. Adverte o transgressor dos perigos da senda pecaminosa. Mostra-lhe a segurança do caminho da salvação. Nutre o espírito do povo com mensagens bíblicas, batiza, faz casamentos, dedica os pequeninos a Deus. Festeja nascimentos e realiza funerais. E ainda cumpre as obrigações burocráticas e administrativas da igreja. Assim é o pastor. Cuida de tudo e de todos. Mas, quem cuida dele? Ou não precisa disso? É porventura um super-homem? Não tem sentimentos? Não precisa de um ouvido, uma mão amiga? ${ }^{11}$

\section{Roseli Kühnrich de Oliveira observa:}

O pastor enquanto pessoa é sujeito a todas as questões humanas, tendo, por conseguinte, necessidades físicas, emocionais e espirituais, entre outras. A busca pela realização pessoal, familiar e vocacional (ou profissional) é relatada por aqueles que se dedicam ao cuidado de outros, mas nem sempre acontece das comunidades de fé atentarem para as necessidades de seus pastores (OLIVEIRA, 2005, p.56-57).

Mesmo sabendo da humanidade do pastor, as pessoas preferem continuar idealizando o seu cuidador. Assim muitos pastores são colocados num pedestal acima dos demais. São considerados inatingíveis pelas dores, dúvidas, fraquezas e erros. Aparentemente não é “espiritualmente correto" ser um pastor bem humano, pois como líder e guia espiritual, ele não pode falhar, nem mostrar fraquezas. Demonstrando fragilidade, iria decepcionar o público.

Desta forma a comunidade está na contra-mão no cuidado do seu cuidador. O desafio está justamente em perceber o pastor como um igual, que está sujeito às mesmas paixões, tentações, reveses e carências, como uma pessoa comum - como um simples mortal. ${ }^{12}$ É salutar para a igreja e para o próprio pastor que se desista desta idealização. A igreja precisa ver mais o pastor-pessoa do que a pessoa-pastor.

Por outro lado, existe o perigo de desvalorizar a pessoa do pastor de tal maneira, que ele sucumbe diante do seu suposto ínfimo significado que ele e seu ministério tem para a igreja e a sociedade. A igreja deve valorizar seus agentes pastorais de tal forma, que haja um cuidado mútuo.

\footnotetext{
${ }^{11}$ Disponível em www.associacaoministerial.org.br, acessado em 09 de jan. 2008.

${ }^{12}$ Nota: Alusão ao texto da Carta de Tiago 5.17, que se refere ao profeta Elias como "um homem semelhante a nós, sujeito aos mesmos sentimentos [...]".
} 


\title{
2.3 RECONHECIMENTO DA NECESSIDADE DE OMBRO
}

A autossuficiência parece ser inerente ao coração humano. Muitos pastores não conseguiram extirpar totalmente este mal do seu coração e da sua mente. Em nome da aparência continuam fazendo carreira solo, procurando lutar sozinhos na esperança de vencerem sozinhos.

Embora Howard Hendricks não se refira diretamente a pastores, sua afirmação também é valida para este grupo de pessoas:

\begin{abstract}
Um número excessivamente grande de homens está tentando conduzir sozinho seu casamento e vida em família, seu trabalho ou seus compromissos espirituais. Eles estão tentando escalar montanhas da proporção do Himalaia com as forças de uma independência austera. Isso não funciona. Homens precisam de mentores, guias maduros que os conduzam pelo caminho (HENDRICKS, HENDRICKS, 2006, p. $30)$.
\end{abstract}

Para ser cuidado é preciso deixar-se cuidar. É necessário haver um reconhecimento da necessidade de cuidado e tomar a decisão de procurar e se expor a um cuidador.

Conforme Dr. Kamaelson, da Índia, ex-vice-presidente da Visão Mundial, após participar de mais de 1200 encontros de pastores, o maior problema dos pastores em nível mundial é que eles têm muita dificuldade de ser ovelhas (ATIENCIA, 2000, p.75).

Então Atiência conclui: "Este cuidado é pessoal e também é mútuo; os líderes devem aprender a cuidar-se e a apascentar uns aos outros. Nós, pastores, temos muita dificuldade de reconhecer que somos "ovelhas". Mas é justamente aqui que começa o processo de cuidar dos outros" (ATIENCIA, 2000, p.75).

\subsection{SUPERAÇÃO DO MEDO DE TER A VIDA EXPOSTA}

Quando pensam em compartilhar dúvidas, questionamentos e lutas pessoais, muitos pastores receiam as consequências e temem pela falta de sigilo ou a desaprovação e desprezo por parte do conselheiro procurado. Assim, por medida de segurança, resiste à exposição dos seus dilemas.

Stu Weber considera em seu livro Um abraço amigo a seguinte experiência como, possivelmente, sendo comum à muitos homens: 
[...] era uma tarefa difícil para mim expor a minha alma para outro homem e admitir não somente a minha necessidade, mas também falar para ele que eu realmente precisava da amizade dele. Eu acho que há alguma coisa dentro de cada um de nós que busca a segurança da obscuridade e, como resultado, nós nunca definimos onde estão nossos relacionamentos. Por isso, homens passam pela vida como ilhas somente tocando as praias de vez em quando, mas nunca realmente deixando que outro homem entre no interior da sua vida (WEBER, 1997, p. 192).

\subsection{REMANEJAMENTO E ADEQUAÇÃO DA AGENDA PASTORAL}

Jaime Kemp questiona a agenda dos pastores, perguntando se ela é amiga ou inimiga. Há pastores que se vangloriam de uma agenda repleta e cheia, acreditando equivocadamente que seu valor e seu significado residem exatamente ali. Kemp denuncia que os pastores são governados, muitas vezes, pela tirania do urgente. E tragicamente o urgente acaba ocupando o lugar do importante. Afirma que "trabalhamos sempre mais para adquirirmos cada vez menos significado no que fazemos. Nosso relacionamento com nosso cônjuge e filhos diminui assustadoramente em qualidade e quantidade" (KEMP, 1996, p.17-18).

Pastores precisam ser auxiliados no entendimento e na aplicação das prioridades de Deus em suas vidas. É relativamente fácil ditar as regras para os outros, mas muitos pastores não conseguem adequar a agenda da vida pessoal sozinhos.

Pr. Edson N. Barbosa insiste com seus grupos de Renovos Pastorais: "Você não pode, sob hipótese alguma, ser escravo da sua agenda. Ela existe para ser sua serva" (BARBOSA, 2004).

A pesquisa revela que $49,4 \%$ dos entrevistados admite que o seu tempo precisa ser remanejado, apesar de 69,1\% expressarem que a agenda é sua aliada e boa serva.

Conforme Peter F. Drucker, citado por Kemp, "O primeiro passo na direção de uma melhor utilização do seu tempo, não é fazer uma nova agenda, mas analisar a antiga" (KEMP, 1996, p.17).

\subsection{APOIO E SUPORTE DA IGREJA LOCAL}

A pesquisa expressa evidências bastante claras da necessidade que os pastores e as pastoras têm de serem cuidados. Transparece a denúncia de que as igrejas não sabem cuidar dos seus líderes pastorais $(44,4 \%$ dos pesquisados se pronunciaram neste sentido, conforme gráfico 10). Os pastores pesquisados, em geral, estão satisfeitos e realizados em seus ministérios, mas sobrecarregados, pois nem sempre suas próprias necessidades são 
consideradas pela comunidade onde atuam e uma boa parcela não encontra um cuidador correspondente para si mesmos.

O apoio da igreja local no cuidado do seu líder pastoral é de suma importância. Não há como aplicar aqui a estratégia do avestruz que esconde sua cabeça na areia, fazendo de conta que consegue assim, ingenuamente, se eximir da realidade que o cerca. A igreja local não pode se esquivar da responsabilidade diante da situação descoberta em que seu líder pode se encontrar. Os membros da igreja precisam ser conscientizados do seu dever para com seu líder espiritual, assumindo a responsabilidade pelas várias dimensões do cuidado que o mesmo necessita. $\mathrm{O}$ apoio e o suporte da igreja local são fundamentais. $\mathrm{O}$ interesse pelo bemestar pessoal do pastor é um investimento que, com certeza, beneficiará a igreja diretamente, principalmente quando considerado a médio e longo prazo.

Os pastores são grandemente encorajados quando seus liderados demonstram interesse em relação ao seu cuidado como pessoas, e não apenas como ministros pastorais. A igreja local e denominacional que reconhece a importância e abrangência deste apoio, aceitará o desafio e fará o possível para que seu cuidador seja muito bem cuidado.

\section{INICIATIVAS NO CUIDADO E PASTOREIO DE PASTORES}

O cuidado preventivo aos pastores é, sem dúvida, urgente e necessário. Não tem como se contentar, oferecendo algumas medidas paliativas, ocasionais, esperando que encontros esporádicos de pastores, congressos ou seminários de atualização e algum encorajamento, serão suficientes. Apascentar os pastores deve fazer parte da agenda da Igreja. Trata-se de um chamado impreterível e um alto clamor de muitos ministros que não pode deixar de ser ouvido e atendido.

Retiros de silêncio e encontros vivenciais regulares poderão ser úteis. Mas o cuidado que pastores necessitam devem ser mais abrangentes. Precisa ser contínuo. Precisa ser pessoal. Precisa ser ombro a ombro.

As igrejas precisam despertar para a necessidade de um Ministério de Apoio aos Pastores. Algumas igrejas têm se importado o suficiente para criar espaços onde os pastores podem se expor sem serem penalizados, falar das suas dores com franqueza e sem medo. A própria igreja acaba sendo beneficiada. Se o cuidador está bem, seu cuidado aos outros será, com certeza, melhor.

David Kornfield, obreiro da Sepal, diz: Algumas denominações têm um dia mensal para o obreiro. Mas essas reuniões ou tratam de assuntos administrativos ou têm pregações 
gerais que, muitas vezes, não atingem as necessidades específicas dos pastores. Outras denominações têm superintendentes ou bispos para supervisionar os pastores. Mas, raras vezes, isto acontece de forma que o pastor sinta o calor de um cuidado pastoral pessoal. Algumas cidades têm conselhos de pastores que se reúnem mensalmente. Isto ajuda com um certo nível de comunhão e unidade, mas, raramente estes pastores chegam a ter o tipo de relacionamento onde poderiam compartilhar problemas íntimos (KORNFIELD, 2006).

Quem entende melhor o conturbado coração do pastor com seus dilemas e prerrogativas, com suas tensões e suspiros, do que outro pastor, que vivenciou e vivencia condições semelhantes? Nada mais indicado e recomendado que um pastor cuide de outro pastor, salvo indícios de necessidade de cuidados especializados e profissionais das áreas psicológicas ou médicas.

Segundo a Editora Sepal, Eugene Peterson é internacionalmente conhecido como “pastor de pastores". A categoria pastoral, em geral, é muito carente em pastores de pastores.

Além da igreja e de iniciativas particulares e isoladas, o próprio pastor precisa se importar o suficiente com o seu cuidado. Se o próprio pastor não priorizar o cuidado de si mesmo e investir um tempo significativo, poucas mudanças ocorrerão na situação atual. Sabese que principalmente pastores tem dificuldade de sossegar, aquietar e relaxar.

\subsection{GRUPOS DE RENOVOS PASTORAIS E AS ALIANÇAS RELACIONAIS ENTRE PASTORES}

\subsubsection{Retrospecto histórico}

No ano de 1984, nas dependências do Lar Rogate, em Curitiba, PR, um grupo de quinze pastores encontrou-se pela primeira vez como fruto da inquietação por um contexto em que pudessem compartilhar seus anseios, áreas de derrota, frustrações, limitações ministeriais geradas por uma preocupação inadequada e consciência de sua necessidade de andar sob um pastoreio e liderança espiritual.

Estes pastores vinham de cerca de oito denominações diferentes e no final daquele encontro nascia a primeira "Célula de Renovo", sob liderança do Pastor Edson N. Barbosa, então diretor Regional Sul da Cruzada Estudantil e Profissional para Cristo. A iniciativa foi chamada de Projeto Oásis, com a visão de Renovos Pastorais, que compreendem células de discipulado e de pastoreio mútuo para pastores, em ambiente fraterno de comunhão, trato pessoal e confronto com estratégias bíblicas de ministério. 
A insígnia do Projeto Oásis é "um ministério voltado para o homem-pastor como pessoa". De acordo com Edson N. Barbosa, "a visão tornou-se parte de todos à medida que começaram a colher os frutos da mesma em suas vidas e ministério, tanto que não puderam resistir ao constrangimento do Espírito Santo no sentido de multiplicá-la.” (BARBOSA, 2004).

\subsubsection{Convivência relacional e pastoreio mútuo}

O singelo objetivo de gerar células de pastoreio mútuo, onde homens e mulheres de Deus encontrassem um ombro amigo onde pudessem reclinar a cabeça nos momentos de cansaço, frustração e dor; onde encontrassem ouvidos dispostos a ouvi-los, mentes e corações dispostos a compreender suas angústias, questionamentos e fraquezas, teve êxito. Vários grupos de Renovo surgiram e se multiplicaram. Até a presente data passaram aproximadamente quinhentos homens e mulheres das mais distintas denominações evangélicas, número que inclui além de pastores, profissionais liberais de ambos os sexos e seus cônjuges. Somente no Uruguai, onde o Projeto Oásis recebeu inclusive definições jurídico-institucionais (Proyecto Oásis), já alcançou a marca de mais de cento e vinte pastores assistidos.

O Projeto Oásis conta com uma casa alugada em São Bento do Sul, SC, chamada "Cantinho do Renovo", onde vários grupos de pastores se reúnem para alguns dias de convívio, edificação e restauração. Mas este lugar apenas é uma referência, pois nem todos os grupos podem se deslocar para São Bento do Sul e procuram lugares apropriados em suas próprias cidades ou adjacentes para assim saírem do contexto ministerial e desfrutarem de um cuidado mútuo.

\subsection{MENTOREAMENTO E A PRESTAÇÃO DE CONTAS VOLUNTÁRIA}

O mentoreamento é um conceito que se tornou mais abrangente e conhecido apenas recentemente, embora praticado desde a antiguidade, muitas vezes, apenas sob outra nomenclatura.

Muitas pessoas, inclusive pastores, estão procurando, de forma consciente ou não, um guia, um treinador, um modelo, um conselheiro para suas vidas, profissões e ministérios. 


\subsubsection{Conceituação}

Segundo Howard Hendricks, a pessoa originariamente chamada Mentor é um personagem da Odisséia, um poema épico grego escrito por Homero. Quando Odisseu (ou Ulisses, como alguns traduzem seu nome), o guerreiro grego e personagem central do poema, partiu para lutar na guerra de Tróia, deixou seu filho Telêmaco aos cuidados de um tutor chamado Mentor. Enquanto Odisseu está ausente lutando em Tróia, Mentor tem a incumbência de criar Telêmaco, promover o seu crescimento e ajudá-lo a se tornar homem. $\mathrm{O}$ cerco de Tróia durou dez anos, e Odisseu levou mais dez anos para voltar para casa. Quando chegou, descobriu que o menino Telêmaco tinha crescido e se tornado um homem, graças à tutela de Mentor (HENDRICKS, HENDRICKS, 2006, p. 153).

Assim Mentor da Odisséia é a origem do termo metafórico mentor, que atualmente é utilizado para indicar uma pessoa acompanhando e orientando outra. Como resultado, mentor pode ter significados diferentes para pessoas diferentes: mestre, guia, exemplo, a figura do pai, professor, treinador, tutor, instrutor, líder, conselheiro, etc.

Há mais tempo o termo mentoria é conhecido no contexto acadêmico onde um professor, muitas vezes na universidade, adota um aluno como seu afilhado ou favorito, investindo nele e ajudando-o avançar de forma especial. Normalmente existe uma afinidade especial entre os dois e o professor enxerga um potencial especial nesse estudante. No mundo de fala inglês o uso do termo foi estendido para todas as áreas: empresarial, artes, igreja e assim por diante.

Segundo Bobb Biehl, citado por Hendricks, "definir o mentoreamento é um tanto difícil, mas descrevê-lo é bem fácil. É como ter um tio que cuida de você por toda a vida e quer vê-lo progredir. Ele não é seu concorrente; está aí para auxiliá-lo, não para competir ou desencorajá-lo. Ele é mais líder de torcida do que crítico" (HENDRICKS, HENDRICKS, 2006, p.160).

Nesta reflexão mentoreamento estará limitado à sua aplicação e relação com pastores. Para a equipe do MAPI (Ministério de Apoio a Pastores e Igrejas) a sugestão para uma definição de mentor específica é a seguinte: "Um mentor é alguém que acredita em outra pessoa, enxergando possibilidades além do que ela percebe, apoiando e nutrindo-a, desafiando e alavancando-a para seu pleno potencial dentro dos propósitos de Deus". ${ }^{13}$

Howard Hendricks testemunha: "Comecei a perceber que para permanecer ensinável e para terminar bem minha caminhada cristã, eu precisava desenvolver um ou mais

\footnotetext{
${ }^{13}$ Site do MAPI, disponível em www.mapi-sepal.org.br/DefinicoesPdeP.htm, acessado em 11 de jan. 2008.
} 
relacionamentos que iriam requerer de mim franqueza e abertura" (HENDRICKS, HENDRICKS, 2006, p. 32).

Ele diz: "Todo homem deve buscar três indivíduos em sua vida: um Paulo, um Barnabé, e um Timóteo" (HENDRICKS, HENDRICKS, 2006, p. 78). Eles representam os três tipos de relacionamento de mentoreamento que uma pessoa (diga-se pastor ou pastora), precisa buscar: um Paulo, alguém mais velho que possa edificar a sua vida; um Barnabé, alguém igual, um irmão de alma à quem possa prestar contas; e um Timóteo, uma pessoa mais nova, para acompanhá-lo e orientá-lo.

Podemos definir um mentor como alguém comprometido com o crescimento e desenvolvimento de outra pessoa e que deseja ajudá-lo em seus objetivos de vida.

Para Hendricks mentoreamento se distingue de discipulado. O discipulado, como é conhecido atualmente, focaliza mais a dimensão espiritual. Na verdade, deveria atingir todas as áreas da vida, ou seja, a vida pessoal, o estilo de vida, o trabalho, os relacionamentos, etc. No discipulado pergunta-se como todas estas áreas se relacionam com Cristo. $\mathrm{O}$ mentoreamento trata menos da instrução do que do relacionamento em levar pessoas à maturidade. Desde que praticado por cristãos, naturalmente o mentoreamento também deveria centrar tudo em Cristo. Enquanto a palavra para discípulo é "aprendiz", a palavra mentoreado vem de uma palavra latina que significa "proteger". O mentoreamento tem por objetivo colaborar na formação do caráter e conduzir o mentoreado a maturidade (HENDRICKS, HENDRICKS, 2006, p. 176).

\subsubsection{Dinâmica do relacionamento entre mentor e mentoreado}

Um mentor é (pelo menos deveria ser) um parceiro vital para o crescimento pessoal, espiritual e ministerial (para não dizer profissional). Sua instrumentalidade no cuidado dos cuidadores pastorais pode ser muito relevante e servir preventivamente para muitos deles.

Hendricks alistou algumas funções práticas de um mentor (HENDRICKS, HENDRICKS , 2006 p. 154-155). Baseado nesta lista, define-se aqui um mentor para pastores como alguém:

- a quem se pode recorrer em tempos de problemas e crises pessoais ou ministeriais;

- que serve de treinador e estimulador. A tarefa de um mentor é preparar o mentoreado para vencer na vida.

- que serve como caixa de ressonância. O mentor fornece ao mentoreado a oportunidade de testar idéias e intuições antes que se tornem agendas e atitudes. 
- que fornece um feedback. O mentor é mais que um espelho. Ele é um comentarista. Ele não apenas vê, mas vê o que importa e indica o caminho.

- que fornece sabedoria. Alicerçado nos princípios bíblicos, o mentor aplica sabedoria à vida pessoal e pastoral de forma que faz sentido e seja eficiente. Pode fornecer novas perspectivas e conselhos práticos.

- que é fonte de informação. O mentor sabe de coisas - particularmente sobre a vida que o mentoreado desconhece.

- que ajuda a delinear planos. O mentor é muito útil e necessário para traçar um programa para o crescimento espiritual.

Naturalmente esta lista não é exaustiva. Provavelmente um mentor não oferecerá todas estas funções, mas algumas delas.

Há pessoas que se opõem totalmente ao mentoreamento, alegando que a palavra “mentor” não está na Bíblia. Fato é que, embora não seja usado o termo, o conceito de mentoreamento era praticado como principal forma de instrução nos tempos da Bíblia. Não era uma inovação ou invenção da cultura grega.

É necessário sublinhar que o mentoreamento implica em relacionamento entre mentor e mentoreado e não em um programa. Além disso, o mentoreamento não precisa, necessariamente, ter características formais e estruturais. Pode, perfeitamente, ser uma abordagem espontânea e informal. Importante é que o relacionamento seja natural - nada artificial.

Geralmente um mentor não oferece seu mentoreamento como um produto de consumo. Isto significa, que ele precisa ser buscado intencionalmente. Aconselha-se procurar um mentor que seja um pouco mais velho que o mentoreado. Mas não existe nenhuma definição sobre a diferença de idades.

Mentores têm algumas marcas significativas que os distinguem de outras pessoas. Hendricks sugere dez características que devem ser observadas num mentor em potencial: 1) O mentor parece ter o que o mentoreado precisa; 2) cultiva relacionamentos; 3 ) está disposto a dar uma oportunidade ao mentoreado; 4) é respeitado por outros cristãos; 5) tem uma rede de recursos; 6) é consultado por outros cristãos; 7) tem a habilidade de falar e ouvir; 8) é coerente no seu estilo de vida; 9) é capaz de diagnosticar as necessidades do mentoreado e 10), está preocupado com os interesses do mentoreado (HENDRICKS, HENDRICKS, 2006, p. 63).

A influência que um mentor pode exercer sobre a vida do mentoreado é profunda e de longo alcance. Evidentemente, não existe um mentor perfeito. As falhas, no entanto, não 
desqualificam um determinado mentor. Importante é observar como o próprio mentor lida com suas falhas e fracassos, e aprender das suas atitudes.

O mentoreamento também pode ser temporário, estendendo-se por um determinado período ou fase da vida. O importante é expor-se e submeter-se à influência e orientação de alguém mais maduro e que tem uma perspectiva de um alcance maior que a própria. Um relacionamento desta natureza fará diferença na vida dos cuidadores pastorais e abençoará indiretamente aqueles que são cuidados.

O MAPI sugere vários modelos práticos de mentoria para pastores: a) formal e informal - formal é um compromisso de se encontrar com o propósito de mentoria e o informal é a mentoria acontecendo como "acidente" no percurso da vida normal; b) especializada - mentor para uma área bem específica; c) vertical e horizontal (recíproca), ou seja, um-a-um e em grupo. ${ }^{14}$

\subsection{PASTOREIO DE PASTORES NO MODELO MAPI}

O MAPI é um departamento da Sepal, que nasceu em 1992, em Belo Horizonte, e que define como sendo sua visão "Cada pastor com um mentor, cada igreja com liderança saudável". ${ }^{15}$ O MAPI compreende que sua missão é apoiar o pastor e assessorar as organizações que o servem, oferecendo modelos e ferramentas para sua saúde e reprodução.

David Kornfield, coordenador nacional do MAPI, já pode ser considerado um ícone no ministério de apoio aos pastores no Brasil. Ele mesmo descreve as estratégias que ele e sua equipe desenvolvem para assistir pastores:

Nós procuramos responder a este desafio de duas formas. A primeira é treinar pastores em como formar discipuladores, começando com a liderança principal de sua igreja. A maioria dos pastores do Brasil entende o discipulado de forma diferente da que Jesus entendeu. Acham que o discipulado é um trabalho, de um a três meses, desenvolvido para ajudar novos convertidos; especialmente aqueles que estão se preparando para o batismo. Em nosso trabalho enxergamos o discipulado de uma forma radicalmente diferente, procurando a perspectiva do próprio Jesus, pois, para Ele, o discipulado foi a formação dos principais líderes da igreja que iriam reproduzir. O movimento de discipulado pretende ajudar o pastor na formação de seus principais líderes, para que estes, por sua vez, comecem seus próprios grupos de discipulado, selecionando as pessoas que teriam a maior possibilidade de liderar outros grupos. Neste movimento cada pastor (e cônjuge de pastor) tem a opção de ter um pastor discipulador e participar de um grupo de discipulado com outros pastores, experimentando, assim, um pastoreio em sua vida.

A segunda forma de respondermos à necessidade do pastor ser pastoreado é por meio de encontros, de três ou quatro dias, onde pastores e esposas podem

\footnotetext{
${ }^{14}$ Site do MAPI. Disponível em www.mapi-sepal.org.br/defminisPdeP3Modelos.htm, acessado em 11 de jan. 2008.

${ }^{15}$ Site do MAPI. www.mapi-sepal.org.br/defqsomosmissao.htm, acessado em 11 de jan. 2008.
} 
experimentar o que é um grupo de apoio pastoral. Nesses encontros também procuramos oferecer ferramentas e treinamento prático em várias áreas, como a de desenvolver uma equipe pastoral na igreja local. Normalmente só fazemos estes encontros onde já existe uma boa base de pastores envolvidos no movimento do discipulado. Temos visto que estes encontros funcionam melhor quando são feitos de forma denominacional, com o apoio e participação da liderança estadual ou nacional (KORNFIELD, 2006).

O MAPI sugere e desenvolve três categorias diferentes de Pastoreio de Pastores: 1) Semanal: quando têm um projeto específico de alta prioridade que os pastores querem completar: 2) Quinzenal: quando um projeto semanal não precisa mais de tanto investimento ou quando esse investimento requer reprodução em outros grupos que irão exigir mais tempo dos líderes para com esses novos grupos e 3) Mensal: adequado para pastores com pouco tempo ou com relacionamentos maduros (por exemplo, depois de estabelecer um alicerce nos encontros semanais e quinzenais e estar numa fase da reprodução do pastoreio para outros).

O MAPI estimulou a multiplicação de uma rede de pastoreio de pastores, apoiando pequenos grupos que promovem o cuidado e a edificação de pastores em praticamente todos os Estados do Brasil.

A Clínica de Mentoria de Pastores e Líderes, de dois dias é o alicerce da visão do MAPI. Leva líderes pastorais e seus cônjuges a ganharem uma visão de um líder que brilha, com um foco na prática da mentoria. Segundo Kornfield, sete relacionamentos são fundamentais para transportar pastores da condição de bons para excelentes: 1) Jesus Cristo; 2) consigo mesmo; 3) sua família; 4) um grupo pastoral; 5) sua equipe de ministério; 6) um líder pastoral, discipulador ou mentor e 7) amigos íntimos.

Além disso, o MAPI oferece ainda uma Clínica de Pastoreio de Pastores, de dois dias, oferecido para pastores e cônjuges.

\subsection{CLÍNICA ESPIRITUAL FERMATA}

O Dr. Edmund Spieker, diretor fundador da Rádio Transmundial do Brasil, diretor internacional pela própria rádio e, por último, conselheiro da Rádio Transmundial, entendendo que Deus o chamou para "ajudar os seus servos a terminarem bem as suas carreiras". ${ }^{16}$ Spieker asseverou que a Fermata foi uma experiência bem pessoal depois que descobriu, após 34 anos de ministério em posições executivas e missionárias em várias organizações, que muitos obreiros, apesar do muito conhecimento adquirido e do esforço

\footnotetext{
${ }^{16}$ SPIEKER, Edmund. Op. cit. Entrevista realizada em 07/12/2007.
} 
concentrado, não tinham uma constante alimentação espiritual para resistir às tentações tanto de fora quanto dentro do seu meio.

Sua preocupação e inquietação tiveram confirmação numa estatística e estudo do Dr. Robert Clinton Jr., que concluem que de cada dez líderes evangélicos, apenas dois terminam bem a sua carreira de fé.

Assim fundou em 2004 o ministério denominado Clínica Espiritual Fermata, direcionado especialmente para pastores, sob tutela da CIM (Churches in Mission), uma agência interdenominacional norte-americana. O nome Fermata ${ }^{17}$ pareceu bem sugestivo para ele e sua esposa Marli, pois vem da palavra Fermare, que significa: afirmar, reafirmar e também numa partitura musical significa uma pausa.

A percepção da importância de pastores terem uma oportunidade de fazer uma recauchutagem, uma restauração, através de um momento de descanso foi fundamental na elaboração do seu novo projeto ministerial de apoio ao líder pastoral. Para Spieker, a base bíblica encontra-se em Mateus 11:28-30, especificamente no versículo 29, quando Jesus convida: "Tomai sobre vós o meu julgo, e aprendei de mim, que sou manso e humilde de coração, e encontrareis descanso para a vossa alma".

A primeira Fermata foi realizada em 2004 na Bahia, na cidade de Luis Eduardo Magalhães. Seguiram-se outras 38 até o momento, com participação média de 45 pessoas, principalmente pastores e cônjuges.

As Fermatas consistem em encontros de 3 a 4 dias e são agendadas de norte a sul, na medida que pastores ou organizações entendem que devem realizar uma "pausa" para um momento de reflexão e de renovação ministerial. A ênfase está em oferecer aos pastores um encontro onde eles possam descansar, onde não precisam investir muito, mas chegar e sentirem-se honrados, abraçados e motivados para estudar aqueles princípios básicos da mensagem da palavra de Deus. As Fermatas pretendem ser uma oportunidade de fazer uma recauchutagem, um refrigério para a alma do líder pastoral.

\subsection{COMPROMISSO PESSOAL PARA TERMINAR BEM}

A igreja precisa aprender a cuidar dos seus cuidadores, assim como o próprio pastor necessita estar comprometido com o cuidado de si. O que ele pode fazer por si, é responsabilidade pessoal e deve fazer em seu próprio favor e da igreja, a que serve.

\footnotetext{
${ }^{17}$ A Fermata é um sinal musical colocado acima ou abaixo de uma nota ou pausa, e tem o significado de "parada", "pausa", ou prolongamento de uma nota ou de uma pausa além do seu valor habitual.
} 
Quando o pastor não termina bem sua carreira ministerial, envolve sofrimento não só para ele. Sua esposa e seus filhos sofrem juntos. Seus cooperadores e equipe de líderes, assim como a própria igreja, sofrem. Acima e além de todos, quem sofre é o próprio Deus. Ninguém sofre sem que Deus sofra também. Se nós pudéssemos ver o coração de Deus em relação a seus pastores veríamos, em muitos casos, um coração dolorido e quebrantado. E, por que não afirmar que inclusive o mundo sofre, ainda que zombe pelo fracasso?

"O autocuidado adequado é um dos segredos menos compreendidos de um ministério florescente", dizem London e Wiseman (LONDON, WISEMAN, 1998, p. 202). "Para cuidar adequadamente de sua boa forma espiritual o pastor tem de reduzir agendas lotadas, pressões de prioridade, expectativas não razoáveis e valores seculares, mas tem de ser feito."

David W. F. Wong aponta, depois que estudou e analisou vários personagens e líderes bíblicos, doze princípios para pessoas terminarem bem. Com certeza são aplicáveis aos cuidadores pastorais, segundo Wong, "Terminar bem é tudo o que importa no fim" (WONG, 2006, p.200-206).

\subsection{CONSIDERAÇÕES SOBRE INICIATIVAS DE PASTOREIO DE PASTORES}

As Fermatas são eventos únicos e ainda não tem nenhuma definição ou visão sobre um atendimento contínuo para os pastores que já participaram uma ou mais vezes dos encontros. Com certeza uma Fermata é uma experiência renovadora, mas há necessidade de repetir esta intenção com certa regularidade, para preservar os estímulos conquistados.

As diversas opções de apoio ao pastor do MAPI são bastante pertinentes e atendem várias necessidades dos pastores. São bem estruturadas, de caráter instrutivo e inspirador, mas há indícios de que tendem a ser formais e um pouco generalistas, não satisfazendo plenamente o cuidado pessoal e personalizado pretendido por um número considerável de pastores.

O comprometimento pessoal do pastor com seu cuidado e sua busca empenhada do mesmo é um elemento significativo e necessário, porém não suficiente. A intenção e o esforço do pastor apenas para cuidar de si, ainda não atende a demanda de receber um pastoreio exercido por um outro cuidador.

Sem desmerecer as diversas iniciativas, a proposta do Projeto Oásis, com os grupos de Renovos Pastorais, parece ser a mais eficaz, pois propõe um pastoreio mútuo, pessoal e contínuo, sob liderança de um pastor cuidador. Enfatiza encontros de convivência e acompanhamento individual, além de alianças relacionais entre os pastores do próprio grupo. 
O cuidado integral do agente pastoral, defendido e pleiteado por Roseli M. Kühnrich de Oliveira, envolvendo o emocional, o cognitivo, o corporal, o espiritual e até o ecológico, dentro do contexto social, ainda seria preferível a todas as propostas que foram mencionadas e avaliadas para a elaboração deste artigo, e digno de total e irrestrito empenho por parte das lideranças eclesiásticas e comunitárias. Falta, no entanto, uma proposta prática, funcional e executável para um cuidado integral de pastores. Evidentemente, será necessário conceber uma parceria de profissionais das relações de ajuda, desenvolvendo uma equipe de acompanhamento e de pastoreio de pastores.

\section{CONCLUSÃO}

Toda abordagem e discussão deste artigo se ocupou com o cuidado que é proporcionado aos cuidadores pastorais. Inicialmente foram apontadas algumas crises e armadilhas que cercam o ministério pastoral e a vida pessoal do pastor.

No segundo capítulo foram apresentadas as respostas e uma avaliação da pesquisa feita junta a oitenta e um pastores de igrejas menonitas em vários estados brasileiros, além da discussão de tópicos relacionados com alguns desafios no cuidado aos pastores. A pesquisa indica que a dimensão do cuidado preventivo e terapêutico necessita ser repensado pelos próprios pastores, como por aqueles que podem e devem proporcionar o cuidado devido a eles. Os encontros de pastores não devem se limitar a reflexões teológicas, assuntos administrativos e ferramentas ministeriais, mas intencionalmente abrir espaço para o pastoreio mútuo e cuidado uns dos outros.

Algumas louváveis iniciativas e propostas de cuidado e apoio aos pastores foram brevemente nominadas e comentadas nesta monografia. Na igreja brasileira, infelizmente, ainda um número reduzido de pastores desfruta ou tem acesso ao privilégio necessário de ser pastoreado.

Para alcançar o objetivo de pastores continuarem exercendo bem o seu ministério pastoral e tendo em vista uma boa finalização, no futuro, é preciso que a igreja, suas lideranças e o próprio pastor se importem o suficiente com a dimensão do cuidado para investirem todos os recursos necessários. O risco de negligenciar esta categoria de cuidado é muito maior para o reino de Deus e a igreja de Cristo do que geralmente se supõe. Sua importância não pode ser suficientemente enfatizada. 
Cuidar e receber cuidados precisa constar na agenda de cada pastor - e também da igreja local. É uma necessidade. Além de muito importante, é urgente. O presente e o futuro agradecem!

\section{REFERÊNCIAS}

ATIENCIA, Jorge. Pastorear e ser Pastoreado. Curitiba: Encontro, 2000. 82p.

BARBOSA, Edson N. Folder de Apresentação e Divulgação do Projeto Oásis. Curitiba, PR. 2004. de 2004.

Projeto Oásis: Pastoreio de Pastores. Encontro do Grupo de Renovo em março

BARNA, George. Líderes em Ação. Campinas: United Press, 1999. 322p.

BÍBLIA. Português. Bíblia Sagrada. Tradução: Nova Versão Internacional. São Paulo: Editora Vida, 2000.

COOPER, Rodney L. Schulter an Schulter: wie Männer zu Brüdern werden (Ombro a Ombro: como homens tornam-se irmãos). Basel: Brunnen Verlag, 1998. 219p.

CRESS, James A. 2000/1 - Pastor de Pastores. Associação Ministerial. Disponível em www.associacaoministerial.org.br Acesso: 09/01/2008.

ESTRESSE. In: Mini-Houaiss: Dicionário da Língua Portuguesa. Rio de Janeiro: Objetiva, 2004.

HENDRICKS, Howard; HENDRICKS, William. Como o Ferro afia o Ferro. São Paulo: Shedd Publicações, 2006. 254p.

LONDON, H.B. Jr; WISEMAN, Neil B. Seu Pastor é uma Espécie em Extinção. São Paulo: Eclésia, 1998. 246p.

Despertando para um grande ministério: um livro de pastor para pastor. São Paulo, Mundo Cristão, 1996. 260p.

LUTZER, Erwin. De pastor para pastor: respostas concretas para os problemas e desafios do ministério. São Paulo: Vida, 2000. 159p.

KEMP, Jaime. Pastores em Perigo. $2^{\text {a }}$ edição. São Paulo: Sepal, 1996. 96p.

. Pastores Ainda em Perigo. $1^{a}$ edição. São Paulo: Sepal, 1996. 117p.

KORNFIELD, David. Pastor também precisa de pastor. 2006. Disponível em http://www.lideranca.org/cgi-bin/index.cgi?action=viewnews\&id=329. Acesso: 10/01/2008.

OLIVEIRA, Roseli M. Kühnrich. Cuidando de quem cuida: um olhar de cuidados aos que ministram a palavra. São Leopoldo: Sinodal, 2005. 147p.

PASQUINI, Eros Jr. Mantendo-se Puro. Raio de Luz. Governador Valadares, $\mathrm{n}^{\circ}$ 103, p.3034, 1996.

PETERSON, Eugene. A vocação espiritual do pastor: redescobrindo o chamado ministerial. São Paulo: Mundo Cristão, 2006. 175p.

O Pastor Contemplativo. Rio de Janeiro, Textus, 2002. 192p.

Um Pastor Segundo o Coração de Deus. Rio de Janeiro: Textus, 2000. 181p. 
POIMEN. In: O Novo Dicionário Internacional de Teologia do Novo Testamento. São Paulo: Vida Nova, 1983. p.469.

QUEIRÓS, Edison. Transparência no Ministério. São Paulo: Vida, 1998. 216p.

SATHLER-ROSA, Ronaldo. Cuidado Pastoral em Tempos de Insegurança. São Paulo: ASTE, 2004. p.143.

SPIEKER, Edmund. As crises pastorais e a estratégia da Clínica Espiritual Fermata. Entrevista realizada em 07/12/2007.

STRONG, Joyce. Líderes à Beira do Abismo. Belo Horizonte: Betânia, 1999. 126p.

WEBER, Stu. Um abraço Amigo. São Paulo: Quadrangular, 1997. 296p.

Guereiro Gentil. São Paulo: Quadrangular, 1997. 260p.

WONG, David W. F. Vida \& Carreira. Decisões sábias em cada etapa da vida. Santa Bárbara d'Oeste: SOCEP, 2006. 216p. 